\title{
The Constitution of Sweden and European Influences: The Changing Balance Between Democratic and Judicial Power
}

\author{
Joakim Nergelius
}

\begin{abstract}
The Swedish Constitution is composed of four constitutional acts, some of which date back more than two hundred years. The central document is the Instrument of Government of 1974. The report observes that the fundamental rights chapter had rarely been applied by the Swedish courts until recent years. Traditionally, the national protection of basic rights is described as weak, as there is neither a constitutional court nor a strong tradition of judicial review by the ordinary courts. Judicial restraint is deemed necessary so as not to undermine the Swedish popular democracy. Thus, in general, EU and international law have enhanced rights protection and judicial review. Areas where constitutional concerns have arisen include the following: (a) freedom of speech enjoys a strong protection in the Constitution and this prompted delays regarding the implementation of the Data Retention Directive, which led to a consequent EU fine; (2) the ECJ ruling in Laval clashed with the right for trade unions to initiate collective action; (3) concerns have been expressed by civil society about limitation of the widespread access to documents where their secrecy may be requested by an international organisation. The European Arrest Warrant has not raised rights concerns in Sweden, although the report finds the ECJ's approach in Melloni to be misguided. The Constitution contains extensive amendments regarding EU and international co-operation, including a fundamental rights based limitation clause that had its origin in the German Constitutional Court's Solange decisions.
\end{abstract}

Keywords The Constitution of Sweden/Instrument of Government Amendment of the Constitution in relation to EU and international co-operation Solange clause - The Swedish Supreme Court - Strengthening of judicial review

Joakim Nergelius is Professor of Constitutional Law, University of Örebro. e-mail: joakim. nergelius@oru.se.

All websites accessed and text submitted 20 January 2015, with some updates and revisions inserted in November 2018.

J. Nergelius $(\square)$

University of Örebro, Örebro, Sweden

e-mail: joakim.nergelius@oru.se

(C) The Author(s) 2019

A. Albi and S. Bardutzky (eds.), National Constitutions in European

and Global Governance: Democracy, Rights, the Rule of Law,

https://doi.org/10.1007/978-94-6265-273-6_8 
through EU and ECHR law - Deference of courts - Laval and impact on collective action, posted workers and freedom of expression - European Arrest Warrant and extraditions - Data Retention Directive, freedom of expression, public protests and EU fine for delay in implementation • Fundamental rights - Melloni, Article 53 EU Charter and the question of a higher standard of protection $\cdot$ Referendums on EU accession and adoption of the euro

\section{Constitutional Amendments Regarding EU Membership}

\subsection{Constitutional Culture}

1.1.1 Without any doubt whatsoever, Sweden falls into the second category of constitutions noted in the Questionnaire. If we take Joseph Raz's distinction between 'thick' and 'thin' constitutions, where the latter are 'simply the law that establishes and regulates the main organs of government, their constitution and powers', while the former have to meet a number of requirements, such as long duration, 'canonical formulation' and entrenchment as a point of departure, ${ }^{1}$ few countries fit better into the 'thick' category than Sweden, with its long, peaceful tradition. Similarly, Besselink makes a distinction between historical and revolutionary constitutions, where the former, like in the UK, Netherlands or Sweden, have developed gradually over a long period, which tends to make them less binding or normative and just as political as legal in their nature. As for the latter, they have been enacted radically, under more dramatic circumstances, in a way that has been formative for the state in question. ${ }^{2}$ It is thus also true that Sweden's constitutional culture has never been influenced to a notable extent by any constitutional traditions in other countries or regions. In fact, the visible change in the attitude of the highest Swedish courts in relation to judicial review during the last few years, under the influence of EU law as will be explained below, is probably the clearest example of this kind of 'constitutional influence'.

1.1.2 The Swedish Constitution is composed of four constitutional acts: the Instrument of Government (Regeringsformen) of 1974; the Freedom of the Press Act (Tryckfrihetsförordningen) of 1949 (but with a history dating back to 1766); the Freedom of Speech Act (Ytttrandefrihetsgrundlagen) of 1991, regulating media other than the printed media; and the Act of Succession of 1809, regulating the right to the throne. On 1 January 2011, the main Swedish constitutional act, the Instrument of Government (IG), was subject to some important changes. This was not its first main reform; for example when Sweden joined the European Union on 1 January 1995, some important changes were made, notably in the field of human rights protection. From a structural point of view, however, this new reform of 2011

\footnotetext{
${ }^{1}$ See Raz 1998, pp. 152-193.

${ }^{2}$ See Besselink 2007 and Nergelius 2009, p. 34.
} 
is probably more interesting, since it mixed the traditional popular sovereignty upon which the Constitution is based with some new elements of judicial review and increased the separation of powers, both in a horizontal and vertical manner.

Since 1974, there has been a chapter on fundamental rights (Chap. 2 IG) in the Swedish Constitution. It is quite similar to the European Convention on Human Rights (ECHR) and must as such be described as extensive; however, until very recent years, it has very rarely been applied by Swedish courts. Thus, the centre of gravity is now gradually moving from a total focus on popular sovereignty to a combination of the traditional ideal pertaining to fundamental rights protection as well as the separation of powers. ${ }^{3}$

\title{
1.2 The Amendment of the Constitution in Relation to the European Union
}

1.2.1 The constitutional regulation covering EU membership as well as other kinds of international agreements is found in Chap. 10, Art. 6 of the Instrument of Government, the main constitutional act. A few words could be said about the historical background for this regulation, which today reads as follows:

\begin{abstract}
Within the framework of European Union cooperation, the Riksdag [Parliament] may transfer decision-making authority which does not affect the basic principles by which Sweden is governed. Such transfer presupposes that protection for rights and freedoms in the field of cooperation to which the transfer relates corresponds to that afforded under this Instrument of Government and the European Convention for the Protection of Human Rights and Fundamental Freedoms.
\end{abstract}

The Riksdag may approve a transfer of authority, provided that at least three fourths of those voting and more than half the members of the Riksdag vote in favour of the decision. The Riksdag's decision may also be taken in accordance with the procedure prescribed for the enactment of fundamental law. Such a transfer cannot be decided until the Riksdag has approved the agreement under Article $3 .^{4}$

Roughly speaking, this Article was introduced when Sweden joined the European Union in 1995, while some other important articles in Chap. 10 that are dealt with below date back to the enactment of the new Constitution in 1974 or even earlier. $^{5}$ Already in 1964 , the possibility to transfer decision-making powers to an international organisation aimed at peaceful co-operation was established, although this could only take place to a limited extent. Although these old provisions could of course not be used to facilitate EU membership, this constitutional reform was

\footnotetext{
${ }^{3}$ See Nergelius 2014, where this recent change is the point of departure.

${ }^{4}$ Quoted from the official publication 'The Constitution of Sweden - The Fundamental Law and the Riksdag Act, Sveriges Riksdag - The Swedish Parliament', Stockholm 2012.

${ }^{5}$ A useful comment on the historical background of this Article, and its history before 1995, is provided by Algotsson 2000, p. 273. See also Holmberg and Stjernquist 2003, pp. 198 et seq. and Bernitz 2002b, p. 28.
} 
thus actually enacted as early as fifty years ago, with the future relation to the European Community in mind (given that Sweden had applied for association with the Community already in 1961). These rules were then transferred to the new Constitution in 1974, with the additional provision that competences could also be transferred to an international court. ${ }^{6}$

However, it may be said that Chap. 10, Arts. 7-10 permit transfers of legislative powers, budgetary powers including the use of the assets of the state and treaty-making power, all to a limited extent, to international organisations other than the EU, while the possibility to transfer rights of decision-making to the EU itself is, and has been ever since 1995, much wider and more general. From a material point of view, such a transfer is thus limited only by the standard of the protection of human rights within the EU.

From what has been said above, it follows that when Sweden was going to join the EU, the question was whether the three formerly last sections of Chap. 10, Art. 5 (now Arts. 7-10) would be sufficient or not. In other words, was a constitutional reform required in order to enable Sweden to join the European Union?

The first committee that attempted to deal with this question, the so-called Constitutional committee for joining the (then) $\mathrm{EC}^{7}$ answered in the affirmative but proposed a new rule in Chap. 1, Art. 10, according to which the supremacy of any kind of EU law in relation to any Swedish law, including the Constitution, should be clearly stated or declared. However, criticism of this proposal was very heavy in the spring of 1993, mainly due to political reasons. It was seen as a sign of Swedish resign or capitulation before Europe and was identified with an unlimited handing over of power to Brussels. ${ }^{8}$ Consequently, the Government quickly proposed three other alternatives, one of which was similar to the one finally chosen. ${ }^{9}$ It should be noted that the solution chosen was very much influenced by certain jurisprudence of the German Constitutional Court, the Bundesverfassungsgericht.

The background to this is that according to Chap. 8, Art. 14 IG, constitutional amendments must be presented in Parliament nine months before a general election and then approved, by a simple majority of the members of Parliament, in two subsequent and identical decisions before and after the election. This rule applies to all four Swedish constitutional acts, i.e. not only to the Instrument of Government but also the Freedom of the Press Act, the Freedom of Speech Act and the Act of Succession noted in Sect. 1.1.2. Such an election was going to take place in September 1994 and thus, in February 1994, it was also decided that a referendum on EU membership should be held in November of that same year. Consequently, the proposal for constitutional reform had to be presented to the Parliament in December

\footnotetext{
${ }^{6}$ Some minor changes were also introduced in 1976 and 1985. See Algotsson 2000, p. 274.

${ }^{7}$ Grundlagsutredningen inför EG SOU (Statens offentliga utredningar, Official Bills and Proposals) 1993:14.

${ }^{8}$ For a further analysis of this debate, see Algotsson 2000, p. 273. See also Bernitz 2002b, pp. 109 et seq., and Melin and Schäder 1999, pp. 168 et seq.

${ }^{9}$ These were all presented in the report Ds 1993:36, Våra grundlagar och EG - förslag till alternativ (Our constitutions and the EC - different options).
} 
1993 at the latest, in order to facilitate EU membership, given that the content of the then Sects. $2-4$ of IG 10:5 ${ }^{10}$ was not sufficient for this. Furthermore, from the point of view of the Government, this proposal had to have a different content or at least a different form than the first, unpopular proposal, which had been seen as a kind of gift to the already very strong 'No' side in the forthcoming referendum.

Compared with the earlier text, the main changes in the new proposal were that the former requirement that transfer of competences could only occur to a limited extent was abolished and, most importantly, that the previous mention of transfers, in general, to an 'international organisation for peaceful cooperation', was replaced by a specific mention of transfer of decision-making powers to the three European Communities (which in 2002 became the EU). However, this transfer could only take place under the condition (or, as it read, 'as long as', 'så länge' (cf. Solange)) that the protection of fundamental rights within the EU was as far-reaching as that envisaged by Chap. 2 IG (dealing with basic human rights) and the ECHR. ${ }^{11}$

Here, the influence of the case law of the German Constitutional Court seems clear. It seems evident that the Governmental committee analysing the constitutional conditions for future EU membership, faced with severe time pressures since it was necessary, due to Swedish constitutional requirements, to present a proposal for constitutional amendment no later than in the middle of December 1993, suddenly stumbled upon the Maastricht judgment of the German Constitutional Court delivered on 12 October $1993,{ }^{12}$ which somehow seemed to indicate a solution to the Swedish dilemma, since it provided conditions for further transfer of decision-making powers and for future development within the EU. Subsequently, the committee also discovered the two Solange judgments from 1974 and 1986, the language of which thus found its way into the Swedish Constitution. ${ }^{13}$ In other words, the position of the German Constitutional Court was suddenly also the position chosen by the Swedish constitutional legislator.

The formulation based on the Solange doctrine ('så länge', 'as long as') was subsequently changed in 2002, giving way, as seen below in Sect. 1.3.3, to the rather vague notion 'the principles of the form of government'. ${ }^{14}$ Nevertheless, the basic content of this former first section of IG 10:5, now Chap. 10, Art. 6, remains the same. So what does this Article mean in reality?

First and foremost, Chap. 10, Art. 6 IG is a rule to be used when new treaties are agreed. It has been used in relation to the ratification of the treaties of Amsterdam, Nice and Lisbon. Thus, it made it possible for Sweden to join the EU once the

\footnotetext{
${ }^{10}$ I.e. the former Sects. $1-3$.

${ }^{11}$ This then means that these two catalogues of basic human rights should be read together, in order to analyse whether the protection within EU law corresponds to their added value of protection of basic human rights. However, the two catalogues are mutually overlapping, albeit with some differences. In reality, if the question were ever to become a real problem, the assessment of the applicable human rights standard could turn out to be quite tricky.

${ }^{12}$ Brunner, BVerfGE 89, 155.

${ }^{13}$ BVerfGE 37, 271 (Solange I) and 73, 339 (Solange II), respectively.

${ }^{14}$ A proposal based on governmental bill SOU 2001:19.
} 
referendum in November 1994 had resulted in a positive 'Yes' vote, but it also made it possible for Sweden to ratify new treaty changes, in a rather uncomplicated manner, since the only material requirement for this was that the protection of basic human rights within the EU continue to be reasonably high (which, as we know, has not been a problem thus far). ${ }^{15}$

The reasons for choosing this particular solution given in the bill introducing this reform were that it would mean that in the future, Sweden would not be bound to accept the legal situation that would exist at the time of joining the EU and that otherwise, the legal acts of the Union could not be questioned in Swedish domestic law by using national rules on the protection of basic rights. According to this line of reasoning, which bears clear traces of arguments used not only by the German Constitutional Court in its Maastricht judgment of 1993 but also by the Danish Supreme Court in a similar judgment in 1998, ${ }^{16}$ legal acts from the EU that fall outside the area where a transfer of sovereignty has taken place (i.e. outside the areas where the Union is competent to act, cf. Arts. 2-4 TFEU) are ultra vires and thus not applicable within the domestic legal system or by the national courts, who may simply set them aside. This may, in fact, be too simplified in reality; the main problem with this line of reasoning is, of course, that according to the settled jurisprudence of the European Court of Justice (CJEU), only the CJEU has the competence to decide whether a particular EU act is in fact invalid (because it is ultra vires or due to other reasons). ${ }^{17}$ Here, national courts and authorities in quite a few Member States seem quite simply not to agree with the CJEU. However, should such a situation occur before a Swedish court, where the court might actually be uncertain as to the validity of an EU rule, it would quite simply have to ask for a preliminary ruling from the CJEU according to Art. 267 TFEU. ${ }^{18}$

A few words should also be said about the formal requirements for a transfer of decision-making powers to the EU. Such a transfer by a single decision of the Riksdag requires a majority of $75 \%$ of the voting members; the alternative is that transfer takes place in the same way as an amendment of the Constitution, i.e. through two identical decisions, one before and one after a general election (cf. Chap. 8, Arts. 14-15). ${ }^{19}$ It may be noted that while Swedish public opinion was for a long time regrettably hostile towards EU membership (as shown most clearly in the controversial referendum on the euro in September 2003), parties that are in favour of membership have had a solid majority within the Parliament, having held

\footnotetext{
${ }^{15}$ Instead, a number of new rules on fundamental rights have been included in the Treaty on European Union, starting with the Treaty of Amsterdam in 1999. Furthermore, the Charter of Fundamental rights was drafted in 2000 and is now becoming more important in the jurisprudence of the CJEU.

${ }^{16} \mathrm{U} 1998.800 \mathrm{H}$.

${ }^{17}$ See for example the well-known Case C-314/85 Foto-Frost [1987] ECR 04199. Cf. on the position of Swedish courts Nergelius 1998a, pp. 156 et seq. and 170.

${ }^{18}$ Cf. Bernitz 2002b, p. 116.

${ }^{19}$ As follows from Sects. 3-4 of this Art., this could actually also lead to a referendum on the issue, should one-third of the Members of Parliament so wish. So far, however, this possibility to hold a referendum on a constitutional amendment has never been used.
} 
more than $80 \%$ of its 349 seats at all times between 1994 and 2018 (and even before). This also means that the transfers of decision-making powers that have been made so far, in 1994, 1998 (Amsterdam) and 2001 (Nice), have all been taken through one single decision, with the necessary majority. ${ }^{20}$

From a theoretical point of view, this type of regulation makes it possible for Sweden to adhere to new treaties or approve treaty changes without a referendum and without having to change the Constitution, which is a practical advantage. Also, the process for ratification as such is uncomplicated, not least compared with the requirements in many other Member States.

The reference to the level of protection of basic rights within EU law is interesting, since this is something which has never before been so clearly identified as an important aspect of the Swedish Constitution. Traditionally, the national protection of basic rights is also rather weak in Sweden, where there is no constitutional court and not even a strong tradition of judicial review by the ordinary courts, as discussed below. Once again, the influence of the German constitutional jurisprudence, 'discovered' by the constitutional legislators at a particular, crucial moment in 1993 may be stressed. Furthermore, since the protection of basic rights within the EU has grown ever stronger since 1994, as mentioned above, it seems clear that Sweden may continue to transfer decision-making powers to the EU.

The new declaratory rule in Chap. 1, Art. 10, which was enacted in 2010, states that Sweden is a member of the European Union and also that Sweden participates within the UN, the Council of Europe and other forms of international co-operation (for the full text see Sect. 3.1.1).

Some further EU provisions on the participation of the Parliament and on the elections of the European Parliament will be addressed in Sect. 1.4.

1.2.2 An important fact to be observed is the relative ease with which the Swedish Constitution(s) may be changed. According to Chap. 8, Art. 14, the constitutional acts or fundamental laws are enacted, changed or amended by means of two parliamentary decisions of identical wording (see also Art. 17). The second decision, however, may not be taken until the elections for the Riksdag have been held and the newly-elected Parliament has been convened. At least nine months shall elapse between the time when the matter is first submitted to the Chamber of the Riksdag and the date of the election, unless the Parliamentary Committee on the Constitution (Konstitutionsutskottet) grants an exception from this provision by means of a decision supported by five-sixths of its members. ${ }^{21}$ It must be noted, however, that

\footnotetext{
${ }^{20}$ A question to be asked in this respect is whether there may be any material differences between what may be transferred to the EU using one or the other of the two procedures. Personally, I believe that neither the wording of Chap. 10, Art. 6 IG nor the practical experience during twenty years of membership points towards any such difference, but the issue has been raised in the doctrine (e.g. by Holmberg and Stjernquist 2003, pp. 199 et seq.).

${ }^{21}$ In Sect. 2 of the same Article it is also stated that the Riksdag may not adopt a proposal for a constitutional amendment which conflicts with another amendment proposal which has already been adopted earlier, unless it rejects the proposal which it first adopted together with the vote on the new proposal.
} 
a qualified majority of the 349 Members of Parliament (MP) is not required on either of these occasions; instead, a majority of the MPs present and voting is sufficient on each occasion, which is surprising from a comparative perspective. Nevertheless, constitutional amendments are normally made in accordance between all main political parties.

A certain degree of protection for parliamentary minorities is provided by Chap. 8, Art. 16, which stipulates that a referendum shall be held on a proposal concerning a constitutional amendment which has been voted by the Riksdag for the first time, on a motion to this effect by at least one-tenth of the MPs, provided that at least one-third of the MPs concur in approving the motion. ${ }^{22}$ The referendum will then be held simultaneously with the election of the new Parliament. The proposal is deemed to have failed if it is rejected by more than half of all votes validly cast. If it is successful, it proceeds to the Riksdag for final consideration.

Still, from an international perspective it seems clear that the Swedish constitutional acts are unusually easy to change or amend, in particular if one takes into account the highly technical nature of the Freedom of the Press Act and Freedom of Speech Act, which both contain extensive sections of criminal, procedural and civil law. This fact has favoured frequent and regular constitutional amendments (in total more than 200) since 1974. In fact, the parliamentary election of September 2006 was the first since 1974 in which no constitutional amendment was proposed. It should also be noted that the possibility to request a referendum on a proposed constitutional amendment, the result of which would be legally binding on Parliament, has so far never been used.

These rules are best understood if one bears in mind their political purpose, which is to facilitate consensus on constitutional changes among the main political parties, notably the Social Democrats and the right-wing parties. In fact, politically disputed or contested constitutional amendments have so far been extremely unusual, which has somewhat mitigated the practical impact of the generous rules on the adoption of constitutional amendments.

1.2.3 In order to explain the reasons why Sweden joined the European Union in 1995, some historical background is necessary. The effects of the economic crisis in the early 1990s were important. Suddenly, Sweden was no longer a model for the rest of the world, but rather a symbol of a societal model that no longer worked and was in need of profound change. The initial response to the crisis by the Swedish population, in the aftermath of the events of 1989, was to be strongly in favour of joining the European Union. At that point, membership of the EU was perceived as a first necessary step towards renewed economic prosperity. Gradually, however, from 1992 until early 1994, this opinion changed and instead the Union came to be seen as a threat to the Swedish welfare state.

\footnotetext{
${ }^{22}$ Such a motion must be put forward within fifteen days from the date on which the Riksdag first adopts the amendment proposal.
} 
Finally, however, Sweden voted in favour of joining the EU in November 1994 (by 52.3\%), after Austria and Finland had both voted in favour. ${ }^{23}$ Economic arguments affected the outcome significantly, but if one compares the Swedish EU debate with, for instance, the situation in Denmark, it may be noted that the idea of the EU as a political instrument was not at all neglected or rejected in Sweden. On the contrary, in 1994 the EU was described by the Social Democrat Government that had just returned to power as a political means to balance the power of global capitalism.

1.2.4 The new Chap. 1, Art. 10 which states that Sweden is now a member of the EU, may be worth noting here once more.

\subsection{Conceptualising Sovereignty and the Limits to the Transfer of Powers}

1.3.1 As follows from Chap. 10, Art. 6 and Chap. 8, Arts. 14-15, the transfer of powers to the EU is quite clearly regulated by the Constitution, while the supremacy and direct effect of EU law that follows from EU membership is not as such regulated or even mentioned in the Constitution (or in any other law for that matter). Instead, this has been left to the courts to regulate and here it is clear that both of these two crucial concepts have now really been acknowledged by the Swedish courts, and thus in Swedish law, as explained below.

1.3.2 It is absolutely clear that the Swedish Constitution is currently going through a transitional phase, moving away from a traditional, total focus on popular sovereignty to a situation characterised by a separation or division of powers between many different actors (or by 'constitutional pluralism').

Swedish courts have acknowledged the supremacy of EU law in some important cases. However, since legal support for the supremacy principle cannot be found in Chap. 10, Art. 6 of the national Constitution, it must instead be derived from the general principles of EU law, which is also what the Supreme Administrative Court did in the important landmark case Lassagård in $1997 .^{24}$

The Lassagard case is of fundamental importance as to the extension of the scope of judicial review in Sweden and its interaction with EU law. It clearly shows that EU law prevails over domestic law. Secondly, it shows that EU law has developed the scope of judicial review in Sweden. Application of the general principle of effective legal protection by the Supreme Administrative Court has led

\footnotetext{
${ }^{23}$ For a comparison with these two countries, and their respective reasons for joining the EU, see Nergelius 2002.

${ }^{24}$ The so-called Lassagård case, Regeringsrättens årsbok (RA) 1997 ref. 65. This case is commented in detail by Nergelius 1998b. See also Andersson 1996. The reinforcement of the tendency towards stronger judicial review from the (supreme) courts was recently illustrated in case NJA (Nytt Juridiskt Arkiv - the Supreme Court's publication of decisions) 2015 p. 298.
} 
to the invalidation of the national regulation limiting such review, and to the adoption of a new provision ensuring the general competence of the administrative courts to review administrative decisions.

Going further, it must be remarked that within Swedish law, EU law offers better protection for basic human rights than the ECHR. This conclusion is based on the fact that Swedish rules were set aside in the Lassagård case because they were contrary to Arts. 6 and 13 ECHR as part of EU law, as well as to the general principles of EU law, not because of the application of the ECHR itself or 'in its own right ${ }^{25}$

In this regard, it is also interesting to note that the Supreme Administrative Court in Lassagård did not refer to the special rule on judicial review in IG Chap. 11, Art. 14. This constitutional provision reflects the traditional Swedish stance on limited judicial review (in 1997 more so than today, as explained below). Thus, the Lassagård case also confirmed that any limitations regarding the power of the court to set aside legislation as unconstitutional do not apply with regard to EU law.

1.3.3 As stated above, the level of protection of human rights within EU law sets the limit here, but since the protection of basic rights within the EU has grown stronger since 1994, as mentioned above, it seems clear that Sweden may continue to transfer decision-making powers to the EU. Another possible limit consists of the rather vague notion of the so-called 'principles of the form of government'. This vague expression was introduced into the constitutional text, Chap. 10, Art. 6, in 2002 and must be understood as referring to the important principles for the Swedish Constitution mentioned in Chap. 1 IG (such as monarchy, local and municipal autonomy and impartiality within the public administration), perhaps in combination with the uniquely Swedish tradition concerning access to documents and protection for 'whistle-blowers' and other media sources, as follows from the two constitutional acts, the Freedom of the Press Act and the Freedom of Speech Act that were noted in Sect. 1.1. Proposals for a referendum on the decisions to transfer sovereignty and decision-making powers to the EU were tabled in relation to the ratification of the EU Constitution in 2005 and the Lisbon Treaty in 2009, but only from the left-wing parties which did not have the number of votes necessary to make this happen.

1.3.4 When Sweden was in the process of joining the EU, the main legal question was whether the former Chap. 10, Art. 5 (now Art. 6) would be sufficient to enable membership. In other words, was a constitutional reform required in order to enable Sweden to join the European Union?

In 1993 the first committee that attempted to deal with this question, the so-called Constitutional committee for joining the EC, answered in the affirmative and proposed adding a new rule to Chap. 1, Art. 10, according to which the supremacy of any kind of EC law in relation to any Swedish law, including the Constitution, should be

${ }^{25}$ See Nergelius 1998b. 
clearly stated or declared. ${ }^{26}$ However, criticism against this proposal was very heavy in the spring of 1993, mainly due to political reasons; it was seen as a sign of Swedish capitulation before Europe and an unlimited handing over of power to Brussels. ${ }^{27}$ Consequently, the Government quickly proposed three other alternatives, one of which was similar to the one finally chosen (the current Chap. 10, Art. 6). ${ }^{28}$

\subsection{Democratic Control}

1.4.1 The European Parliament is not mentioned in the Swedish Constitution (except in IG, Chap. 8, Art. 2 Sect. 1 p. 6, which makes a short reference to the organisation of elections to the European Parliament). However, a by-law regulation of the Swedish Parliament concerning its functions in respect of European affairs can be found in Chapters 7, 9 and 10 of the Riksdag Act (Riksdagsordningen). In fact, it has been changed recently, as will be explained below.

Furthermore, according to Chap. 10, Art. 10 IG the Government shall keep the Parliament continuously informed and confer with bodies appointed by the Riksdag with regard to developments within the framework of EU co-operation. ${ }^{29}$ In practice, this consultation and information is done through regular information provided by ministers to a specific parliamentary committee, the so-called EU-nämnden. More detailed regulations on how this information shall take place are found in Chap. 10 of the Riksdag Act.

The parliamentary EU Committee is not a regular committee like the other parliamentary committees, which are regulated in Chap. 7 of the Riksdag Act. Still, it is mentioned in Chap. 7, Art. 14 of the Riksdag Act, which, according to the rules on amendment of that Act in Chap. 8, Art. 16 IG, means that it cannot be abolished by a simple legislative majority. The Committee's composition reflects and is based on the outcome of the general elections.

Some important changes in the Riksdag Act entered into force on 1 December 2009 (i.e. on the same day as the Lisbon Treaty) concerning specific procedures related to supervision of the principles of subsidiarity and proportionality. Based on a report from the Constitutional Committee, ${ }^{30}$ a document-based or sector-specific model of scrutiny of the principle of subsidiarity, according to which the nature of the matter that will be reviewed determines which of the parliamentary committees

\footnotetext{
${ }^{26}$ Grundlagsutredningen inför EG, supra n. 7.

${ }^{27}$ For a further analysis of this debate, see Algotsson 2000, p. 273 et seq. as well as Bernitz 2002b, p. 109 et seq. and Melin and Schäder 1999, pp. 168 et seq. (who were both members of this legislative committee).

${ }^{28}$ These three were all presented in the report Ds 1993:36, supra n. 9.

${ }^{29}$ More detailed rules concerning the obligation to inform and consult are laid down in the Riksdag Act.

${ }^{30}$ KU (Konstitutionsutskottet - the Constitutional Committee) 2009/10:2.
} 
(of the total of twenty) will be responsible for exercising the new test introduced by the Lisbon Treaty, was introduced. The parliamentary committee may, within two weeks, ask the Government to give its opinion on whether the legislative proposal in question violates the principle of subsidiarity. If the majority of the committee should then find that the principle of subsidiarity has been violated, this will also probably become the official Swedish position. The committee will make a statement or report to the Swedish Parliament, suggesting that it declare the position of the committee to be the official position of the Parliament, and that the Parliament should subsequently send this reasoned and justified position to the presidents of the European Commission, Council and European Parliament. Furthermore, should the contested act nevertheless enter into force, the Parliament may, in line with the Protocol on the application of the principles of subsidiarity and proportionality, urge the Government to initiate proceedings before the Court of Justice. ${ }^{31}$

Nevertheless, the various committees dealing with other political issues are far more established and have greater decision-making power, notably in legislative and budgetary issues, while the EU committee has until now been seen only as a forum for discussion and information.

Normally, formal hearings of the ministers take place before the meetings of the Council of Ministers, according to the rules in Chapters 9 and 10 of the Riksdag Act. The requirement is that at least five members of the EU Committee must request a hearing. Although this is relatively informal and unregulated, the ministers are supposed to represent an official, Swedish line that enjoys the support of a significant majority of the MPs.

Concerning the new rules on amendment of the Treaties (Arts. 48-49 TEU), the Parliament shall, according to a new rule in Chap. 9, Art. 20 of the Riksdag Act, approve or reject any such new initiative, having first heard the responsible committee on its views.

It may be noted that the obligation for the Government to inform the Parliament has expanded and includes all documents originating from the EU (Riksdag Act Chap. 9, Art. 22).

In this respect, it may also be worthy of mention that issues related to TTIP, the Transatlantic Trade and Investment Partnership, not least concerning future parliamentary supervision in external trade matters, were greatly discussed in the campaign for the elections to the EU Parliament in May 2014. ${ }^{32}$

1.4.2 Only two referendums have been held in Sweden. The first was held in November 1994, in which $52.3 \%$ voted for membership and $46.7 \%$ were against. The second was the legally extremely doubtful referendum on European Monetary Union (EMU) membership in September 2003, in which 56.7\% voted against. While the first referendum was held for an obvious reason, the background of the second referendum might perhaps warrant further explanation.

\footnotetext{
${ }^{31}$ See KU 2009/10:2 p. 8.

${ }^{32}$ See e.g. a survey of all the party leaders in the daily Svenska Dagbladet, 19 May 2014.
} 
The reason for this peculiar Swedish deviation from its obligations as an EU member simply has to do with domestic politics. After the referendum on EU membership in 1994, only two official No-side parties, the Environmentalists and (former) Communists, together with the small Farmers Party, which had been in favour of EU membership as such but were opposed to the idea of a common currency, demanded a referendum on this matter. Thus, a huge parliamentary majority was against holding a referendum. However, upon returning to Swedish domestic politics in the fall of 1997 and after having acted as a UN peace broker in Bosnia for two years, the right-wing opposition leader and former Prime Minister (at the time of writing Foreign Minister) Carl Bildt, in a surprising move during a parliamentary debate in the build-up to the 1998 parliamentary election, called for a referendum to be held on this special topic. Since he had at that time already consulted the Liberals and the Christian Democrats, only the governing Social Democrats (who held $45 \%$ of the seats in Parliament) at that time did not formally support the idea of a referendum, which meant that this idea suddenly became a political reality or even necessity. It may also be added that the Social Democrats never formally opposed the idea, which was logical given the internal division within the party over this issue. Thus, no political party or force, including the media, ever really opposed the idea of organising a referendum on EMU, at least not on legal grounds. The very simple legal fact that EU membership and the result of the referendum in 1994 did not formally or legally allow for this second referendum was never really invoked in the Swedish debate, which is quite surprising. ${ }^{33}$

From a legal point of view, it is clear that Sweden has already since 1997, when the original decision was made not to participate in the third step of EMU, violated its obligations as an EU member. Sweden thus became the first country to meet the so-called convergence criteria but not to participate in the EMU, without any legally binding exception that enables it to remain outside (unlike in the case of Denmark and the UK). However, the introduction of Art. 139 TFEU, with the enactment of the Lisbon Treaty, has probably made Sweden's situation easier from a strictly legal point of view, since Sweden may now be treated as a Member State 'with an exception', like Denmark or the UK - even though no such exception has ever really existed.

As it turned out, $57 \%$ of the voters voted against the euro on 14 September 2003, only three days after the assassination of Foreign Minister Anna Lindh towards the end of the campaign. It may be asked if the result might have been different, had the Government spent more time and energy arguing in favour of the common EU currency already in 1999 or 2000.

The legally rather unclear situation to which the referendum led is all the more regrettable since all the other constitutional preparations for full membership in the EMU were conducted or implemented already in 1998-1999, in accordance with

\footnotetext{
${ }^{33}$ For the only real exception from this, see Bernitz 2002a, Chap. 3 and Bernitz 2002b, Chap. 9 (which were written and published before the EMU referendum). See also Nergelius 2008.
} 
the provisions of IG Chap. 8, Arts. $14-15 .{ }^{34}$ Generally, these consisted of amendments to Chap. 9 Arts. 12 and 13, regulating the financial power of the Realm. According to these rules, the Riksbank (central bank of the Realm), which works under the Riksdag and is formally independent from the Government, is responsible for monetary policy. No public authority may determine how the Riksbank decides in matters of monetary policy. The eleven members of the governing council of the Riksbank are all appointed by the Riksdag, which also considers whether the members of the Governing Council or the Executive Board of the Bank shall be granted discharge of responsibility. A member of the Executive Board may be removed from office only if he no longer fulfils the requirements laid down for performing his duties or if he has been found guilty of gross negligence. All of these rules, aimed at ensuring the independence of the Riksbank, meet the criteria laid down in the TFEU for enabling Member States to join the EMU.

Thus in fact, all possible practical measures in Swedish public life during the last twenty years, be they economic, legal or constitutional, have been directed towards facilitating full Swedish membership in the EMU and adopting the euro as the national currency. The only thing that has been lacking is a clear will on the part of the main political parties.

\subsection{The Reasons for, and the Role of, EU Amendments}

1.5.1 Since the Swedish Constitution has never been amended to a considerable extent in relation to the EU, the question on the reason for amendments is difficult to answer. As mentioned above, however, the influence of the German Constitutional Court is clearly visible. Apart from this, domestic Swedish political considerations have had much to do with subsequent developments, both in the elaboration of Chap. 10, Art. 6 IG and in the events leading to the euro referendum.

1.5.2 For the factors that influenced the EU amendments, refer to Sects. 1.2.1-1.2.2. On the question of whether the Constitution may become obsolete in this respect, this is not the case in Sweden, since the constitutional solution chosen is very flexible, as described above, and will allow for the further transfer of sovereignty and decision-making power to the EU for a long time yet, when the EU treaties are changed further.

1.5.3 In my assessment, it is hard to give a general answer to the question on the role of national constitutions in the context of transnational governance, since conditions undoubtedly differ between different countries. Generally speaking, my view is that governments and politicians throughout the world ought to devote more

\footnotetext{
${ }^{34}$ It may also be noted, in this respect, that Sweden actually conducted a severe economic policy, characterised by austerity, in 1994-1996, in order to meet the convergence criteria necessary for EMU membership, which makes the subsequent development even less logical and harder to understand.
} 
time and energy to defending and explaining the need for globalisation and the need for the institutional reforms that it may cause, instead of defending old-fashioned national sovereignty or simply acting as if this were still the basic condition for political action. Yet to transform this general view into specific constitutional recommendations is difficult. Nevertheless, specific shortcomings in individual countries may of course be identified.

\section{Constitutional Rights, the Rule of Law and EU Law}

\subsection{The Position of Constitutional Rights and the Rule of Law in the Constitution}

2.1.1 Chapter 2 of the Instrument of Government is rather long (25 Arts.) and contains provisions on most of the human rights enumerated in various catalogues of this kind, e.g. the well-known conventions of the United Nations and the Council of Europe. What is striking, however, is the emphasis put on the techniques and possibilities for limiting the scope of the rights by ordinary legislation.

The European Convention for the Protection of Human Rights and Fundamental Freedoms has in fact been a part of Swedish law since 1 January 1995. No law or other provision contrary to Sweden's obligations under the Convention may be promulgated (IG Chap. 2, Art. 19). The exact meaning of this is, however, unclear, as opinions differ as to what the status of such a law should be, if it were promulgated nevertheless. Even the preparatory documents are silent on this issue. Given the sceptical attitude of most of the political parties in Sweden towards judicial review, it was impossible to write into the Constitution that the ECHR would prevail over a conflicting Swedish law, since this would have enabled Swedish courts to set aside Swedish laws in a potentially high number of cases. Still, it seems to be difficult to avoid the conclusion that Swedish courts indeed would have to do precisely that when serious conflicts between the two legal systems arise.

The applicable and binding rules on human rights in Sweden are to be found in Chap. 2 IG, in the Freedom of the Press Act of 1949 and the Freedom of Speech Act from 1991, as far as freedom of speech in books and the media is concerned and finally, since 1995, in the ECHR. Chapter 2 IG guarantees the freedom of expression, freedom of information, freedom of assembly and manifestation, freedom of association and freedom of worship to all citizens. As far as the freedom of expression is concerned, reference is made to the Freedom of the Press Act and the Freedom of Expression Act, which regulate freedom of expression in the media. Some forms of free speech, such as art exhibitions and theatre performances, are exclusively protected by Chap. 2 IG. The same applies to political meetings, subject to the condition that they are not broadcast; in the latter case, the Freedom of Expression Act is applicable. 
Chapter 2 protects the 'negative' dimension of the above-mentioned freedoms. All citizens are thus protected against coercion by the public authorities to disseminate or not to disseminate their political, religious or cultural views, to participate in or abstain from a meeting or manifestation or to join or quit a political, religious or cultural association.

As concerns procedural rights, it has to be noted that retroactive legislation is prohibited both in penal and tax law (IG 2:10), and that courts may not be established for specific cases. More complicated is the provision that every citizen shall be entitled to a hearing before a court if he is deprived of his liberty after having committed a crime or because he is suspected of such an act (or for other reasons). Here, the definition of deprivation of liberty has caused some difficulties in relation to administrative sanctions like the obligation imposed on foreigners to reside in and not leave certain municipalities (which, however, have now been abolished).

Some further rights are protected by the constitutional text but in weaker terms, such as the right to exercise a trade and to practice a profession or the rights of the Sami population. This is also true for the protection of property, which was reinforced in 1995 but is still rather easy to restrict (although compensation must always be promptly paid).

We may also note the weak or unclear legal position that the ECHR has in Swedish law, where, according to IG Chap. 2, Art. 19, no act of law or other provision may be adopted which contravenes Sweden's obligations under the Convention. The ECHR as such was incorporated through an ordinary law (1994:1219). Still, this does not say anything about what would actually happen should a Swedish law nevertheless be contrary to this provision (an issue that is not dealt with in a satisfactory way by the travaux préparatoires either). ${ }^{35}$ In other words, the supremacy of the ECHR in relation to Swedish national law is nowhere expressly recognised.

2.1.2 Chapter 2, Arts. 12-13 as well as Arts. 20-24 IG are in one way or another concerned with limitations of the rights guaranteed in Chap. 2. Articles 20-24, which will be focused on here in greater detail, are somewhat complex. The relation between these articles is that Art. 20 mentions articles that may be limited by law, while Arts. 21-22 lay down general conditions for restrictions of the rights that may in fact be restricted. Articles 23-24 then regulate more closely the conditions for the restriction of the different forms of free speech and freedom of information, assembly and manifestation as well as of association referred to in Art. 1 .

Article 20 begins by mentioning that these rights, together with those guaranteed in Arts. 6 and 8 as well as the right of public attendance at a court trial, may in fact be restricted by an Act of Parliament. Such restrictions may, however, be imposed only to achieve purposes that are acceptable in a democratic society, and must never be disproportionate with regard to such purposes. Furthermore, they may not be extended so far as to constitute a threat to the free formation of opinion, and must never be imposed solely on the grounds of political, religious, cultural or other

${ }^{35}$ For criticism against this fact, see Bernitz 2002a. 
opinions. A parliamentary minority which comprises at least one-sixth of the MPs voting on the issue has the right to postpone the final adoption of a law restricting the exercise of basic rights (Art. 22). Whether a bill is in fact of this restrictive kind will be decided by the Constitutional Committee (Konstitutionsutskottet). As for the other freedoms guaranteed in Chap. 2 (Arts. 14-18), they may be restricted by law in accordance with the conditions in the provision defining the right. The constitutionality of such legislation, e.g. in relation to property, may of course be reviewed by the courts.

The rights related to free speech may be restricted for the purposes defined in Arts. 23 and 24, e.g. public safety, the integrity of the individual and national security. Some of these purposes, such as national supply of vital goods and services, may seem a bit odd as a justification for the restriction of freedom of speech, as may the circulation of traffic as a justification for restricting freedom of assembly. It may also be observed that the freedom of expression may always be restricted 'where particularly important grounds so warrant', a limitation formulated in very broad terms.

Generally speaking, the scope of the individual rights guaranteed in Chap. 2 IG is quite comprehensive, but the emphasis on the conditions and the forms in which they may be restricted reflects the general tendency towards parliamentary rule discussed above. Apart from the five-sixths majority required for the rejection of a request for the postponement of the adoption of a law restricting certain basic rights (in particular rights related to freedom of speech and personal liberty), qualified majorities are not needed in order to restrict or limit a fundamental right.

2.1.3 Judicial review The Swedish legal system is based, like most other legal systems in the world, on the idea of a hierarchy of norms. However, in the Swedish Constitution, this may only indirectly be deduced from the provision on judicial review in Chap. 11, Art. 14 IG, according to which courts or other public bodies may set aside provisions that are in conflict with rules of fundamental law 'or other superior statutes'.

This provision would be meaningless without an existing hierarchy of norms. Nevertheless, the concept has in fact never been developed in greater detail in Swedish constitutional law; it may even be said that the concept of the Constitution as higher law or lex superior was not clearly understood when the Instrument of Government was adopted in 1974. At that time, a perspective highly influenced by the principle of popular sovereignty prevailed, according to which the Constitution is above all descriptive, containing the procedures which have to be followed in the exercise of governmental powers, e.g. in the enactment of laws or the appointment of the Prime Minister. The opposite and internationally widely accepted view of modern constitutionalism, according to which the Constitution is the higher law against which all other laws have to be measured, has received greater attention only quite recently, in the last ten years.

Once again, the main trait or characteristic feature of the Swedish Constitution, identified here as IG, is its emphasis on popular sovereignty. According to the very first sentence in Chap. 1, Art. 1 IG, '[a]ll public power in Sweden proceeds from the 
people'. This is a declaratory statement directed against the concept of separation of powers, since courts are never elected by the people, but also a general attitude that has also influenced other parts of the Swedish constitutional system for a long time.

Historically speaking, it may be noted that judicial review of legislation did not become a part of the constitutional text until 1979, when Chap. 11, Art. 14 IG was enacted. The existence of judicial review as such has, however, been discussed in the legal doctrine at least since the 1880s. It was generally acknowledged by the doctrine in the 1930s and finally accepted as fact by the Supreme Court in a case in $1964 .{ }^{36}$

It was not, however, until 1979, in the second reform wave of the new Constitution of 1974, that judicial review was finally written into the new constitutional text. This was, however, limited by the reservations that followed from the requirement of manifest error, and also by some influential political statements in some of the travaux préparatoires, notably from the Constitutional Committee, on the restraint on the part of the courts that was necessary so that this new possibility for the courts would not gradually undermine the Swedish popular democracy. ${ }^{37}$

In the text, that was not changed between 1979 and 2010, Chap. 11, Art. 14 stated that if a court or other public body found that a provision conflicted with a rule of fundamental law or other superior statute, or that a procedure laid down in law had been disregarded in any important respect when the provision was made, the provision could not be applied. However, if it had been approved by the Parliament or the Government, it should be waived only if the error was manifest (the so-called uppenbarhetskrav). Thus, judicial review pertained both to the courts and other public authorities, a fact that has in reality probably diminished the importance of judicial review.

Since 1 January, 2011, Chap. 11, Art. 14 has the following wording:

If a court finds that a provision conflicts with a rule of fundamental law or other superior statute, the provision shall not be applied. The same applies if a procedure laid down in law has been disregarded in any important respect when the provision was made.

In the case of review of an act of law under paragraph one, particular attention must be paid to the fact that the Riksdag is the foremost representative of the people and that fundamental law takes precedence over other law. ${ }^{38}$

The second section of this Article in particular may be subject to analysis. It may of course be seen as an attempt to reconcile the old popular sovereignty with the somewhat new elements of separation of powers and judicial authority. However, it

\footnotetext{
${ }^{36}$ NJA 1964, p. 471, concerning opening hours in shops (although that law was actually considered to be constitutional). For a thorough historical account, see Nergelius 2010, pp. 198 et seq.

${ }^{37}$ See in particular KU 1978/79:39, p. 13.

${ }^{38}$ An identical rule on judicial review of the public authorities now exists in Chap. 12, Art. 10 IG.
} 
has also been suggested that it above all underlines the supremacy of the Constitution, since it is the Parliament that enacts or changes the Constitution (see Chap. 8, Arts. 14-17). ${ }^{39}$

One thing that is clear from the wording of Chap. 11, Art. 14, however, is that the review exercised may be either formal or material in nature. What is not quite clear from the Article is whether the courts have an obligation to exercise judicial review whenever they find such a situation in a case before them or whether they may do so only when the argument is being raised by the parties in a case. ${ }^{40}$ Surprisingly enough, this issue has still not been resolved.

What is clear, however, is that there seems to exist no autonomous right to an abstract judicial review, independent of a specific case or dispute. This was established already in a case in $1987,{ }^{41}$ and the European Court of Justice in the so-called Unibet case recently confirmed that EU law does not impose any specific conditions on the Member States in terms of allowing specific forms of judicial review, as long as effective remedies do indeed exist before independent courts of law. $^{42}$

From jurisprudence, although not from the text itself, it also becomes clear, logically enough, that judicial review is not of a law or some other rule in itself, but rather of the practical use or application of the rule by a public authority in a specific case. ${ }^{43}$

Access to justice The rights pertaining to access to justice are found in Chap. 2: Art. 9 guarantees the right to have any deprivation of liberty on account of (suspicions of) a criminal act or for other reasons examined before a court of law without undue delay, and Art. 11 prohibits the establishment of courts for specific cases and guarantees public proceedings within a reasonable time. Additionally, Chap. 11, Art. 5 IG provides that legal disputes between individuals may never be settled by authorities other than courts of law, except in accordance with the law (such as arbitration bodies).

The rule of law On the specific points raised in the Questionnaire in point 2.1.3, the rules in Sweden are as follows:

- The rule that only published laws can be valid is self-evident and has never been questioned or even discussed.

- Legal certainty and non-retroactivity: as mentioned above, these follow partly from Chap. 2, Art. 11. The principles of nulla crimen sine lege or nulla poena

\footnotetext{
${ }^{39}$ See Karlson 2009, pp. 269-274.

${ }^{40}$ See Nergelius 2010, p. 210 for further discussion.

${ }^{41}$ NJA 1987, p. 198.

42 Case C-432/05 Unibet [2007] ECR I-02271.

${ }^{43}$ For some very clear examples of this, see the two so-called Kurd cases, NJA 1989, p. 131 and 1990, p. 636. Also NJA 1986, p. 489 may be observed here.
} 
sine lege are guaranteed in penal law in Chap. 2, Art. 10 Sect. 1 and in tax law (with many exceptions), in Sect. 2 of that same Article. ${ }^{44}$

- The rule that the imposition of obligations, administrative charges or penalties and criminal punishments is only permissible on the basis of a parliamentary statute, and that sanctions cannot be applied retroactively and cannot be inferred from objectives by virtue of teleological reasoning or by analogy: in addition to Chap. 2, Art. 10 IG, this also follows from Chap. 8, Art. 2 Sect. 1 p. 2, as well as Chap. 8, Art. 3, Sect. 1 p. 1 e contrario. Both of these rules stipulate that a law is necessary to regulate these matters. ${ }^{45}$

The rule of law as such is mentioned in one single Article in the Swedish Constitution, namely in Chap. 8, Art. 22 concerning the important Law Council, which will be subsequently explained in more detail. In order to understand the historically rather limited impact of judicial review in Swedish law, it is not enough to be aware of the heavy emphasis on popular sovereignty in Swedish political and constitutional thinking. The important work of the Law Council, ${ }^{46}$ which since 1909 has exercised a form of judicial preview of law proposals, must also be taken into account in this respect. ${ }^{47}$ According to Chap. 8, Art. 20 IG, the Law Council, which consists of justices or former justices of the two supreme courts, shall pronounce opinions on draft legislation. The opinion of the Council is obtained by the Government or sometimes by a committee of the Riksdag. In order to better understand how the Council works, Art. 21 shall be quoted in extenso, in its official version from 2010:

An opinion of the Council is obtained by the Government or, in accordance with what is stated in the Riksdag Act, by a Parliamentary Committee.

Such an opinion shall be obtained before the Parliament enacts

A fundamental law relating to the freedom of the press or the corresponding freedom of expression on sound radio, television and certain like transmissions and certain like transmissions and technical recordings;

an act of law restricting the right of access to official documents;

an act of law under Chapter 2, Art. 14-16, Art. 20 or Art. 25;

an act of law concerning automatised treatment of personally identified or classified information;

an act of law relating to local taxation or a law which otherwise imposes duties on the municipalities;

an act of law under Art. 2 Section 1 p. 1 or $2^{48}$ or an act of law under Chapter 11 or 12 , or an act of law amending or abrogating any law under points $1-6$ above.

\footnotetext{
${ }^{44}$ Although this right is thus very limited, the Supreme Court nevertheless upheld it and set aside a contradictory law in the case NJA 2000, p. 132.

${ }^{45}$ See here also the case NJA 2005, p. 33, which illustrates this.

${ }^{46}$ In the official English translation this is called the Council on Legislation.

${ }^{47}$ Thus, the creation of the Law Council stands in a close relation to the simultaneous establishment of the Supreme Administrative Court, with both reforms aimed at distributing the many tasks that the Supreme Court had under the old Constitution of 1809 to new bodies.

${ }^{48}$ I.e. of Chap. 8.
} 
The foregoing does however not apply, if obtaining the opinion of the Council on Legislation would delay the handling of legislation in such a way that serious detriment would result. If the Government submits a proposal to the Riksdag for the making of an act of law in any matter referred to in sentence one, and there has been no prior consultation of the Council on Legislation, the Government shall at the same time inform the Riksdag of the reason for the omission. Failure to obtain the opinion of the Council on Legislation on a draft law never constitutes an obstacle to the application of the law.

Chapter 8 Art. 22 further provides as follows:

The Council's scrutiny shall relate to:

1. the manner in which the draft law relates to the fundamental laws and the legal system in general;

2. the manner in which the different provisions of the draft law relate to one another;

3. the manner in which the draft law relates to the requirements of the rule of law. ${ }^{49}$

Whilst there is some uncertainty about the exact scope of this scrutiny, it is important to note two main limitations to the power of the Council. The first is that failure to obtain an opinion from the Law Council will never constitute an obstacle to the application of the law. This fact could lead to the conclusion that the Council lacks importance, but that is hardly correct. In Swedish doctrine, the meaning of the criteria established in Sect. 3 of the provision has been vividly discussed. ${ }^{50}$ In short, there seems to be a general agreement that not only the text of a draft law but also its travaux préparatoires must be taken into account. Since 1995, the assessment by the Law Council must also include an analysis on the compatibility of the draft law with EU law and the ECHR.

The Law Council today feels more free to criticise proposals also from the point of view of the rule of law (rättssäkerhet), which may have something to do with, generally speaking, a lower quality of legislation today compared to 20 years ago, when the pressure to produce laws quickly was much less severe.

The second limitation is that the Government and the Parliament are free to ignore the warnings of the Law Council. This is formally possible, since the opinions of the Law Council are never formally binding. The issue of what constitutional status may be given or attributed to the opinions of the Council is still somewhat unclear. They are of course much more important than ordinary comments on legislation from NGOs or public authorities, since the Council is a body of legal expertise, which represents no party interests and comments on draft laws, i.e. finished legislative products which the Government intends to submit to the Parliament, and not merely on the work of a legislative committee or some similar group.

\footnotetext{
${ }^{49}$ This is the only Article of the Constitution that mentions the rule of law. Sections 4-5 are omitted.

${ }^{50}$ See Nergelius 2010, p. 185 et seq. with further references.
} 
In general, the Law Council does definitely not lack influence or the ability to affect the final versions of the laws adopted by the Parliament. ${ }^{51}$ Still, given the clear statements and formulations in Chap. 8, Art. 21 IG, it would be impossible to claim that the opinion of the Law Council should have a higher status than a contradictory opinion of the Parliament, which enacts a law despite the Council's objections. But in such a case, which is far from unusual, the fact that the opinions of the Law Council have not been observed by the legislator may be one reason why it might be easier for a court to set aside a law in a subsequent case of judicial review.

\subsection{The Balancing of Fundamental Rights and Economic Freedoms in EU Law}

2.2.1 The balancing of fundamental rights with economic free movements rights has not given rise to any major problems. The most contested case so far has been the Laval case, which was referred to the CJEU from the Swedish labour court (Arbetsdomstolen), which in a subsequent ruling found that the Builders Trade Union had to pay Laval compensation of circa 55,000 EUR. ${ }^{52}$ Both this judgment and the ruling of the CJEU in late $2007^{53}$ were very unpopular with the strong Swedish trade unions. However, one constitutional issue which in my view has been neglected in the discussion of this case is that the conflict was not between free movement and the crucial freedom of association as such, but 'only' between free movement and the right for trade unions to initiate collective action, including, in this case, blockades. In the Swedish Constitution, the freedom of association enjoys very strong protection and is difficult to limit or encroach upon (IG Chap. 2, Art. 1 Sect. 1 p. 5 and Art. 20, Sect. 1 p. 2), while the right to initiate collective action is merely mentioned in the Constitution and applies only to the extent that this follows from law or a collective agreement (Chap. 2, Art. 14). This matter is not discussed in the judgment of the CJEU and may have been of no practical importance in this case, but illustrates that this is not a likely area for conflicts between EU law and the Swedish Constitution.

There have been other areas where free movement rules have conflicted with social values rather than constitutional rules, such as the Franzén case. ${ }^{54}$

\footnotetext{
${ }^{51}$ Cf. Nergelius 2010, pp. 194 et seq. for a recent analysis.

52 AD 2009:89.

${ }^{53}$ Case C-341/05 Laval [2007] ECR I-11767.

${ }^{54}$ Case C-189/95 Franzén [1997] ECR I-05909. Case C-405/98 Gourmet [2001] ECR I-01795 may also be mentioned, in which a periodical called Gourmet which specialised in food and wine had published some outspoken commercial advertising for wines, which the Consumers Ombudsman wanted to put an end to (by invoking not least FPA Chap. 1, Art. 9 p. 1). The Stockholm City Court asked for a preliminary ruling from the CJEU, which found the Swedish prohibition against this kind of advertisement far-reaching and problematic. Both the City Court
} 


\subsection{Constitutional Rights, the European Arrest Warrant and EU Criminal Law}

On the relevant constitutional provisions regarding nulla poena, non-retroactivity and access to courts, see Sect. 2.1. However, the European Arrest Warrant (EAW) has not raised constitutional issues in Sweden.

\subsubsection{The Presumption of Innocence}

2.3.1.1 The courts try to assert the criteria for extraditions according to the Arrest Warrant and the Swedish law (2003:1156) that implemented the EAW into Swedish law. So far, however, the question of presumption of innocence has not given rise to any debate in relation to these matters.

2.3.1.2 The point of departure is that Swedish courts will grant extradition requests, provided that there is no reason to doubt the quality or impartiality of the legal system in the requesting Member State. The main criteria for these decisions were laid down by the Supreme Court in 2007, in a case in which it was established that an international convention (the UN Convention on the Rights of the Child) could not be invoked in order to prevent an extradition. ${ }^{55}$

\subsubsection{Nullum crimen, nulla poena sine lege}

2.3.2.1 The principles of nullum crimen and nulla poena sine lege are very clearly protected in Chap. 2, Art. 10 IG.

\subsubsection{Fair Trial and In Absentia Judgments}

2.3.3.1 In absentia judgments (tredskodomar) are allowed in Swedish law, but only in the case of petty crimes. Given the standard in Swedish law, the judgment in Melloni $^{56}$ was very surprising, since it is indicative of a very poor and simply unacceptable human rights standard. ${ }^{57}$ This is quite easily understood when looking at the case.

and the special Market Court (Marknadsdomstolen) then found it impossible to maintain the prohibition (MDA 2003:5).

${ }^{55}$ NJA 2007, p. 168. This case is commented upon critically by Herlin-Karnell 2007.

${ }^{56}$ Case C-399/11 Melloni [2013] ECLI:EU:C:2013:107.

${ }^{57}$ See Nergelius 2013b, p. 815 et seq. 
Compared to the Akerberg Fransson case ${ }^{58}$ decided on the same day, the judgment in Melloni raises some fundamental issues that are likely to cause more confusion in the field of EU constitutional law, for many reasons and perhaps for a long time, not least concerning fundamental rights. One of the reasons for the somewhat - in my view - odd outcome of the case and one of the main difficulties for the CJEU seems to have been the interpretation of the EAW Framework Decision, ${ }^{59}$ which in its original 2002 version prescribed that all Member States were to execute extraditions from other Member States according to the principle of mutual recognition. At the same time, however, Art. 5 of the text contained certain guarantees, with the clarification that if someone is requested for extradition where the person has been sentenced in his absence, there should be a possibility to have the sentence and judgment reviewed. Yet in the new Framework Decision of $2009,{ }^{60}$ it is stated that these guarantees do not apply if the person requested for extradition has been represented by a lawyer and if he knew about the procedure against him and the fact that he might be sentenced in his absence.

Despite the fact that there may be reasons for these harsh rules - such as interest in making the Arrest Warrant work smoothly and, in Italy, the combatting of organised crime - the situation here was complicated, even more so since the CJEU actually neglected to inform the readers of its judgment on the knowledge of such facts that Mr. Melloni might have had during the lengthy procedures.

Unfortunately, the judgment as such is quite short. The CJEU referred to the principle of mutual recognition and stated that extradition must take place in a case such as this, at least if the convicted person was aware of the trial against him and had had the possibility to be represented by a lawyer (or was aware of the fact that a judgment against him might be given in his absence). The CJEU further claimed that the right to be present at a trial may be limited, thus arriving, in a not very convincing or persuasive line of reasoning, at the conclusion that the Framework Decision (in particular Art. $4 \mathrm{a}(1)$ ) does not violate Arts. 47-48 of the EU Charter of Fundamental Rights. While this argumentation is not convincing and may definitely be criticised, another aspect of the case, in my view, is more worrying.

As is well known, Art. 53 of the Charter states that none of its rules may limit or infringe upon the fundamental rights that are acknowledged by EU law, international law, international conventions to which the Member States are parties or the constitutions of the Member States. The possibility for national courts to maintain a higher standard for individuals in this respect than provided by the EAW (as interpreted by the CJEU) was, however, simply dismissed by the CJEU, since this

\footnotetext{
${ }^{58}$ Case C-617/10 Akerberg Fransson [2013] ECLI:EU:C:2013:105.

${ }^{59}$ Council Framework Decision of 13 June 2002 on the European arrest warrant and the surrender procedures between Member States (2002/584/JHA), [2002] OJ L 190/1.

${ }^{60}$ Council Framework Decision 2009/299/JHA of 26 February 2009 amending Framework Decisions 2002/584/JHA, 2005/214/JHA, 2006/783/JHA, 2008/909/JHA and 2008/947/JHA, thereby enhancing the procedural rights of persons and fostering the application of the principle of mutual recognition to decisions rendered in the absence of the person concerned at the trial, [2009] OJ L $81 / 24$.
} 
would 'undermine the principle of the primacy of EU law inasmuch as it would allow a Member State to disapply the legal rules which are fully in compliance with the Charter where they infringe the fundamental rights guaranteed by that state's constitution'. But is that not exactly what national courts ought to do, if they take Art. 53 of the Charter seriously?

This particular line of reasoning of the CJEU is well-known from cases such as Costa v. Enel ${ }^{61}$ and Simmenthal ${ }^{62}$. It basically means that any kind of EU law, primary as well as secondary, is superior to any kind of national law of the Member States, including the national constitution. The latter part of this constitutional jurisprudence is not accepted by very many Member States or their highest courts.

However, in this case the CJEU first, before upholding its jurisprudence on this last point, managed to find that the secondary EU law in question (EAW) was compatible with the applicable primary EU law - the Charter, which itself states that it is inferior in relation to any farther-reaching protection of human rights that may be found in a national constitution. Thus, the CJEU has managed a double operation, both steps of which are most doubtful, in order to 'save the life' of the EAW, which has obviously been seen as very crucial. But while saving this patient, has not the 'life' or at least the legal status of the arguably considerably more important Charter been sacrificed instead, given that its Art. 53 has so evidently been applied and interpreted $e$ contrario, in reality losing its significance? At least that is what follows from a close reading of the judgment.

Concerning the general implications for human rights within EU law, the CJEU stated that the possibility for a national court to refuse extradition is a case such as this would spread doubt on 'the uniformity of the standard of protection of fundamental rights as defined in that framework decision', which would, consequently, undermine the principle of mutual recognition and ultimately the confidence between the legal systems of the Member States. But if this line of reasoning is to be followed, prison sentences for as long as ten years rendered in the absence of the accused are generally to be accepted in the EU of today, which is highly surprising. This, or anything similar, would never be accepted or possible in Swedish law.

\subsubsection{The Right to a Fair Trial - Practical Challenges Regarding a Trial Abroad}

2.3.4.1 Travel expenses are normally not needed, since they fall on the requesting state. For translation costs and legal aid the answer is also no, but here the result may depend on the circumstances of the specific case. According to the EAW and other conventions, the defendant has the right to have all documents in the case translated into his or her language. If Sweden were to hand over e.g. a Polish citizen to Poland, translation would not be a problem for obvious reasons, but in other

\footnotetext{
${ }^{61}$ Case C-6/64 Costa v. E.N.E.L. [1964] ECR 01141.

${ }^{62}$ Case C-106/77 Simmenthal [1978] ECR 00629.
} 
cases, translation is the responsibility of the requesting state. Basically, this is also the case for legal aid, where various conventions guarantee legal representation in the requesting state. The Swedish law on legal aid (2000:562) may be applied in certain situations where no other possibilities or means for such aid exist.

There is no need for a special body to assist extradited persons. As far as I can see and according to the spokesperson of the Swedish Prosecutors International Chamber, this is not urgently needed.

2.3.4.2 According to the spokesperson of the Swedish Prosecutors International Chamber, there are no statistics available with regard to subsequent acquittals and, what is more important, based on the routines that are being followed, it would not be possible to obtain any. When an extradition occurs, the Swedish prosecutor's office sends copies of the decision to the colleagues in the requesting state, but there is no corresponding obligation for that bureau to report back on the result - and thus this simply does not happen. Generally speaking, more documents are handed over - in both directions - in cases concerning extradition for someone who is to stand trial in the requesting state than for someone who is being extradited in order to serve a sentence that has already been decided.

On examples of individual cases, see below under Sect. 2.3.5.4.

\subsubsection{The Right to Effective Judicial Protection: The Principle of Mutual Recognition in EU Criminal Law and Abolition of the Exequatur in Civil and Commercial Matters}

2.3.5.1 No, no such conclusion with regard to effective judicial protection may be made. Generally speaking, this has not been a big problem in Sweden. The courts have applied the rules loyally, which has not caused much discussion.

2.3.5.2 No debate has taken place on the suitability of transposing mutual recognition to criminal law. My own view is that there might perhaps be a future need for such debate, should the position of the CJEU in Melloni prevail. The discussion is interesting, but maybe slightly premature.

2.3.5.3 There has been a certain amount of debate, ever since the late 1990s, on this alleged new role for the courts ${ }^{63}$ as bodies facilitating European legal and judicial cooperation. It is a matter that is often debated e.g. in annual meetings between the Ministry of Justice and academics. ${ }^{64}$ However, issues such as the increased power of courts and the 'judicialisation of politics' have led to much more discussion, both in the legal doctrine and the public debate.

2.3.5.4 There have been no calls for a specific procedure of judicial review. However, it may be noted that as a result of the probably best known case,

\footnotetext{
${ }^{63}$ See e.g. Lindblom 1997, p. 316 et seq.

${ }^{64}$ See e.g. Svensk Juristtidning 2004, p. 205 et seq.
} 
concerning a young man Calle Jonsson, there was a public outburst when he was extradited to Greece in late 2004. He was accused of stabbing a Greek person with a knife at a bar in Rhodos in 2001 and then arrested in Greece from August 2001 to February 2002. Having returned to Sweden, he did not wish to go back to Greece for the trial but was forced to do so after a lengthy procedure, during which public opinion and the media were clearly on his side, thus displaying a clear lack of faith in the impartiality and competence of the Greek authorities. He was acquitted in the trial in April 2005, but the Supreme Court of Greece decided thereafter in November 2006 that the trial had been invalid due to procedural irregularities and should be restarted. So far, however, this has not happened and Mr. Jonsson does not seem to be obliged to return to Greece.

I would probably not support the reinstatement of some form of judicial review, since the need for this does not seem to be urgent. However, this assumption is based on the fact that there is a mutual trust between the courts and legal authorities of all of the EU Member States.

\subsubsection{Constitutional Rights Regarding Other Aspects of EU Criminal Law}

A few examples may be given, of which the matters related to the Akerberg Fransson case are the most important. The Supreme Court in two rulings in June and July 2013, on the grounds of the ne bis in idem principle, made a U-turn as regards the approach to imposing a tax surcharge on a person and prosecuting the same person for a tax offence in different legal proceedings. In the first ruling, a unanimous plenary ruling in June $2013,{ }^{65}$ the Supreme Court found that the long-established Swedish double sanction system (tax surcharge and criminal sentence), in which two different legal procedures were applied where a person had provided false information in a tax return, was not compatible with the ne bis in idem principle. It is clear that this important change in the Swedish legal position was brought about by the decision of the Court of Justice in the Akerberg Fransson case in 2013. ${ }^{66}$ Later, in a follow-up ruling in July 2013, ${ }^{67}$ the Supreme Court established that as a consequence of the change in the law, a person has the right to a new trial if the person has paid a tax surcharge and has in addition been sentenced in a criminal proceeding for a tax offence. The Supreme Court set the cut-off point for the right to use this extraordinary legal remedy at 10 February 2009, when the European Court of Human Rights (ECtHR) issued its seminal judgment in the Zolotukhin case. ${ }^{68}$ Zolotukhin clarified that the ne bis in idem principle in the ECHR

\footnotetext{
65 NJA 2013, p. 502.

${ }^{66}$ Case C-617/10 Akerberg Fransson, supra n. 58.

${ }^{67}$ NJA 2013, p. 746.

68 Sergey Zolotukhin v. Russia [GC], no. 14939/03, ECHR 2009.
} 
prohibits a new prosecution or trial for an offence when it arises from identical or substantially the same facts as the first offence already prosecuted or tried.

In the months following these two rulings, a substantial number of persons were released from prison sentences for tax offences, and many ongoing tax offence prosecutions were terminated.

The issue of whether it is legally possible under the ECHR to apply separate legal proceedings for tax surcharges and tax offences based on the same information in a tax return had been debated in Sweden for a long time. In 2002, the ECtHR found that the Swedish system of tax surcharges was criminal in nature. ${ }^{69}$ However, these decisions did not make the legislator change the Swedish legislation, and neither did the courts change their practice. Obviously, the legislator wanted the taxation system to be enforced by sharp sanctions, as Sweden is a country with high taxes.

However, the sharpened definition of what constitutes ne bis in idem in the Zolotukhin judgment in 2009 made the problem urgent. The Supreme Court ruled on the matter in two new decisions in 2010-2011. In the 2010 decision, which focused on the ECHR law, the majority of the justices took the view the Zolotukhin judgment did not give 'clear support' to the need to change Swedish practice. ${ }^{70}$ This might be seen as an attempt to prevent an expansion of judicial review of legislation by Swedish courts, given that the previous requirement for 'manifest error' in IG Chap. 11, Art. 14 was going to be abolished on 1 January 2011.

In the 2011 case $^{71}$ the defendant invoked the ne bis in idem principle in Art. 50 of the Charter of Fundamental Rights. The case partly concerned tax surcharges for undeclared VAT. A Supreme Court majority, three Supreme Court justices, concluded that the Swedish legal provisions on tax offences and tax surcharges lay outside the scope of the Charter, and that no preliminary ruling was thus required. Two dissenting justices took a different view and concluded that the legal position was not clear regarding the possible applicability of the Charter, and that a preliminary ruling should thus be requested. The Supreme Court therefore voted on whether a preliminary ruling should be requested from the CJEU. As is well known, according to Art. 267 TFEU, the highest instance is obliged to request a preliminary ruling if a case pertains to EU law, unless the legal position is clear (acte clair). Obviously, the Supreme Court did not observe this obligation. In its Akerberg Fransson judgment the CJEU reminded the Supreme Court of the duty to observe Art. 267 TFEU as interpreted in the CILFIT case. $^{72}$

In Sweden, decisions from the Supreme Court are not formally binding on lower courts. Still, they are almost always followed. However, in this case, some judges in

${ }^{69}$ Janosevic v. Sweden, no. 34619/97, ECHR 2002-VII and Vä̈tberga Taxi Aktiebolag and Vulic v. Sweden, no. 36985/97, 23 July 2002.

70 NJA 2010, p. 168.

71 NJA 2011, p. 444.

${ }^{72}$ Case 283/81 Cilfit and Others [1982] ECR 03415, para. 47 in the Akerberg Fransson judgment, n. 58 . 
lower courts found the position taken by the Supreme Court clearly wrong and refused to follow it. This much-observed 'revolt' among Swedish judges forms an important part of the background to the Akerberg Fransson case, in which a district court judge in a small town, Haparanda, in the very north of the country, decided to question the established Swedish system by asking the Court of Justice for a preliminary ruling. ${ }^{73}$

Another example that led to considerable discussion concerned EU Directive 2012/363 on the protection of the financial interests of the European Union. ${ }^{74}$ The Parliament decided on 17 October 2012, in line with the Committee, to issue a motivated opinion to the EU, stating that Directive 2012/363 violates the principle of subsidiarity. ${ }^{75}$

\subsection{The EU Data Retention Directive}

2.4.1 The EU Directive $(2006 / 24)^{76}$ on electronic data retention has been controversial in Swedish law for a long time. Sweden did not implement it in due time (i.e. by 15 September 2007), which led to infringement proceedings against Sweden before the CJEU, which found in 2010 that Sweden had violated EU law. ${ }^{77}$ Finally, the Directive was implemented through a law adopted by the Parliament in March 2012, but before that, the opposition parties had used a rule in the IG (Chap. 2, Art. 22) according to which laws that limit fundamental rights may be postponed one year, as explained above. Since Advocate General Cruz Villalon delivered a critical opinion on the Directive in December 2013, a renewed debate on the Directive and its effects on personal integrity emerged. The judgment in these two cases delivered on 8 April 2014 was thus eagerly awaited, and the fact that the CJEU declared the directive incompatible with the fundamental rights that form a part of EU law means that the legal status of the Directive and the implementing law within Swedish law is today uncertain. The Minister of Justice has stated that the law remains in force, while the surveillance authority, Post-och telestyrelsen (PTS), has made comments pointing in the other direction. A subsequent legal survey has concluded that the Swedish law foresaw the new judgment and is thus applicable. However, the judgment in December 2016 in Tele 2 counters this. ${ }^{78}$

\footnotetext{
${ }^{73}$ See in particular Zetterquist 2012, p. 353 et seq.

${ }^{74}$ See JuU 2012/13:8. (Justitieutskottet - the Committee of Justice).

${ }^{75}$ Rskr 2012/13:8.

${ }^{76}$ Directive 2006/24/EC of the European Parliament and of the Council of 15 March 2006 on the retention of data generated or processed in connection with the provision of publicly available electronic communications services or of public communications networks and amending Directive 2002/58/EC, [2006] OJ L 105/54.

${ }^{77}$ Case C-185/09 Commission v. Sweden [2010] ECR I-00014.

${ }^{78}$ See respectively, Ds 2014:23, Datalagring, EU-rätten och svensk rätt (EU Law and Swedish Law) and Case C-2013/15 Tele 2 [2016] ECLI:EU:C:2016:970.
} 


\subsection{Unpublished or Secret Legislation}

2.5.1 No issues regarding unpublished legislation have arisen. Here I would go as far as to say that the whole concept of secret legislation, of any kind whatsoever, is totally unknown in Sweden, the 'promised land' of transparency, and would certainly never be accepted here.

\subsection{Rights and General Principles of Law in the Context of Market Regulation: Property Rights, Legal Certainty, Non-retroactivity and Proportionality}

2.6.1 In Sweden, EU law has primarily enhanced the protection of general principles. There are some well-known cases, notably from the late 1990s, when the Supreme Administrative Court very soon after EU accession acknowledged principles such as proportionality and legitimate expectations. Another very important case dealt with by the Supreme Administrative Court in 1999 concerned the closure of a privately owned nuclear reactor, Barsebäck $1 .^{79}$ Here, criticism was raised against the court for deciding such a crucial and complicated issue, which involved many aspects of both EU law and national constitutional law, without asking for a preliminary ruling from the CJEU. The main tendency is however clear, namely that Swedish courts have now definitely accepted the supremacy of EU law in relation to national law. ${ }^{80}$

An important illustration is the so-called Klippan case of the Supreme Administrative Court. ${ }^{81}$ The case concerned an undertaking (Klippan) that produced paper in 1965-1975 at a lake in the south of Sweden. In 1975, the property was transferred to another company (Modo AB). In 1989, environmental legislation was modified, permitting the authorities to hold an undertaking liable to pay damages even after the transfer of a property. The environmental protection agency wanted Klippan to pay a sum of approximately six million SEK to clean the water of the polluted lake. Although the 1989 legislation entered into force after the transfer of the property from Klippan to Modo, the government considered that Klippan was liable under the 1989 legislation to pay for the environmental sanitation work. Finally, the governmental decision was quashed by the Supreme Administrative Court, which emphasised that there are only limited possibilities to modify or revoke an administrative decision creating rights due to the entry into force of new legislation. It remarked that in certain circumstances the retroactive application of legislation is constitutionally prohibited (IG 2:10). Moreover, it

\footnotetext{
${ }^{79}$ Regeringsrättens Arsbok (RÅ) 1999, ref. 76.

${ }^{80}$ Cfr. Bernitz 2002b, p. 127 in fine print.

${ }^{81}$ RÅ 1996 ref. 57.
} 
referred to EU law and its general principles that generally do not take into consideration situations preceding the entry into force of the legislation, invoking the proportionality principle and the principle of legal certainty (or security) and the protection of legitimate expectations. This EU exception contrasts with previous national jurisprudence ( $\mathrm{R} \AA 1988$ ref 132) that, arguably, allowed free-floating exceptions.

\subsection{The ESM Treaty, Austerity Programmes and the Democratic, Rule-of-Law-Based State}

2.7.1 General legal aspects of the Treaty Establishing the European Stability Mechanism (ESM Treaty) have been discussed, but not in relation to the rather technical aspects mentioned in Sects. (a)-(c) of the question. ${ }^{82}$ This may be explained by the fact that Sweden is not an EMU member and is not bound by the ESM Treaty.

Various aspects of the Fiscal Compact have been discussed. Concerning the Fiscal Compact, the general assumption is that the changes in the budgetary process and in Chap. 9 IG made in the late 1990s in order to battle the financial crisis and prepare Sweden for EMU membership as described above, are sufficient to meet the demands set out in the Compact.

2.7.2 Once again, the issue has been discussed from some legal points of view but not from this perspective as such, which may have to do with the fact that Sweden has not intended to join the Banking Union from the start.

2.7.3 Sweden has not been subject to a bailout or austerity programme.

\subsection{Judicial Review of EU Measures: Access to Justice and the Standard of Review}

2.8.1 Here I must make a disclaimer, since the Swedish Court Administration (Domstolsverket) could not provide me with exact data on judicial review, as they no longer provide this type of service, which has caused practical problems in terms of obtaining precise figures. Additionally, the CJEU (where I have been in touch with the Registry (Greffe), information and research and documentation offices) has been unwilling to hand out any other material than what can be found in the Court's

\footnotetext{
${ }^{82}$ See among other material the governmental bill for the fiscal pact Ds 2012:30 Fördraget om stabilitet, samordning och styrning inom ekonomiska och monetära unionen (Treaty on Stability, Coordination and Governance in the Economic and Monetary Union) and Nergelius 2013a, pp. 61-83.
} 
Annual Reports. However, since 1995, Swedish courts have asked for preliminary rulings in some 120 cases, of which 76 were submitted between 1995-2008, and the remaining 31 since 1 January 2009. At the end of 2004, when Sweden had been a member for 10 years, the total number was 50 cases. In other words, the frequency is increasing, which may be the result of criticism from the EU Commission to the Swedish government in $2004 .{ }^{83}$ Unfortunately, at the time of writing, I can thus not answer questions (b) and (c).

2.8.2 Until 2013, the standard of review was not perceived as a problem from a Swedish point of view. On the contrary, the standard and intensity of the review exercised by the CJEU must be seen as having positive consequences, given the traditional judicial self-restraint of the Swedish courts. A concrete example of how the CJEU has inspired a bolder attitude among Swedish judges is a case from 2013, when the Akerberg Fransson judgment was followed by a plenary judgment of the Supreme Court upholding the ne bis in idem principle and setting the Swedish law on tax surcharges aside. ${ }^{84}$

\footnotetext{
${ }^{83}$ The criticism that may then be raised against Swedish courts in this respect has a lot to do with the way in which they have used the instrument of preliminary ruling, in accordance with Art. 267 TFEU. The above-mentioned Barsebäck case is one of the best known cases where criticism has been expressed towards a Swedish court for excessive restraint from this point of view. With this debate in mind, it was interesting to note that the EU Commission, in an opinion in 2004, addressed some critical questions to the Swedish Government concerning the attitude of Swedish courts towards their obligations under Art. 267 and concerning the Swedish legislation on this point (2003/2161, C (2004) 3899). The background to the reaction is somewhat peculiar. In Case C-99/00 Lyckeskog [2002] ECR I-04839, the Court of Appeal in Gothenburg, in a minor criminal case, posed the question of whether it could be considered as a court of last instance in the meaning of former Art. 234 (now 267) Sect. 3 (which means that it would in that case be under an obligation to refer any question concerning the interpretation of EU law to the CJEU). Secondly, should that have been held to be the case, the Swedish court wanted to know whether it would have been able to ignore some of the very strict criteria (the so-called acte clair doctrine) of the CILFIT case. The CJEU answered the first procedural question in the negative and then did not bother to answer the second one. However, when posing the questions to the CJEU, the Swedish court adequately described the Swedish procedural system and pointed to the fact that the Supreme Court and the Supreme Administrative Court only review cases from the respective Appellate Courts under a system of admissibility (prövningstillstånd), based on the possibility of a given case to be a future precedent. Furthermore, when deciding not to grant admissibility, the two highest courts were not under any obligation to justify or motivate (or argue in favour of) such decisions. The European Commission, which had intervened in the Lyckeskog case, reacted against these requirements and declared that the Swedish procedural rules, in particular the possibility for the two highest courts to dismiss an appeal for admissibility in cases which may contain complicated EC law matters without having to justify their decisions, made it impossible for the European Commission to fulfil its task as the guardian and 'watchdog' of the Treaties and EC law in general. It thus required the Swedish government to change the legislation in this field. This was also done through the law (2006:502) with certain rules on preliminary rulings from the CJEU, which states that the two supreme courts may never refuse admissibility when a preliminary ruling has been requested by the applicant without a justified statement and reasons.
}

${ }^{84}$ NJA 2013, pp. 502 and 746. 
However, the surprising outcome of the Melloni case and the poor human rights standard that it reveals - that may even undermine the Charter of Fundamental Rights - may lead to another conclusion for the future, and the future jurisprudence of the CJEU in human rights matters needs to be closely followed and analysed. Cases such as Kadi $I I^{85}$ and the Data Retention Directive judgment ${ }^{86}$ indicate that the CJEU maintains a sharp awareness of human rights matters and that Melloni was perhaps (hopefully) just an unfortunate deviation. ${ }^{87}$

2.8.3 On the domestic approach to judicial review, the situation has changed in recent years, but in quite another way. Generally speaking, Swedish courts are by tradition very cautious, as described above, but recent constitutional changes and developments in European law, by the European courts, have brought about some profound and important changes in the last few years. The cases on ne bis in idem have been mentioned above, as has the important work of the Law Council. A statistical analysis of the case law of Swedish courts in the years 2000-2010 made by Karin Åhman reveals that cases relating to the ECHR were most frequent within the case law of the administrative courts of appeal and the general courts of appeal. In 19 of 47 cases the Supreme Court applied the ECHR in such a way that it had a concrete impact on the interpretation of Swedish law. In some cases, however, the ECHR was directly applicable; this was especially the case regarding Art. 13 of the ECHR. The majority of the cases, however, concerned criminal and procedural issues. The Supreme Administrative Court dealt with the ECHR in 25 of 153 cases. In only in 8 of these 25 cases did the Supreme Administrative Court recognise the ECHR in such a way that it came to influence the interpretation of Swedish law. Most frequent was the application of Art. 6 ECHR. ${ }^{88}$ The study also revealed an increased willingness among the courts to apply European law, including European case law, more directly.

Generally speaking, the courts seem more loyal towards the case law of the CJEU than of the ECtHR. However, this loyalty towards the CJEU has not always brought the courts to actually set aside Swedish law by referring to such case law. It should be noted that regarding Arts. 6 and 13 of the ECHR, the courts have tended to increase their adherence to the case law of the ECtHR.

Concerning the Swedish Constitution, Swedish courts have set national laws aside for being unconstitutional three or four times since 1996 (depending on what is counted as setting a law aside or giving it a new interpretation, an issue that will not be dealt with here) ${ }^{89} \mathrm{~A}$ very important case concerning the IG was decided by

\footnotetext{
${ }^{85}$ Kadi II, Joined cases C-584/10 P, 593/10 P and 595/10 P Commission and Others v. Kadi [2013] ECLI:EU:C:2013:518.

${ }^{86}$ Joined cases C-293/12 and C-594/12 Digital Rights Ireland and Seitlinger and Others [2014] ECLI:EU:C:2014:238.

${ }^{87}$ See also Case C-131/12 Google Spain and Google [2014] ECLI:EU:C:2014:317.

${ }^{88}$ See Åhman 2011.

${ }^{89}$ One such case is the so-called Manga case of 2012 (NJA 2012 p. 400), which concerned possession of some 40 Japanese art drawings of naked, prepubescent youngsters. In this case, the
} 
the Supreme Court in April 2014, ${ }^{90}$ when a person who had been wrongly deprived of his Swedish citizenship was awarded compensation in the amount of 100,000 SEK due to the fact that the tax authority had violated Chap. 2, Art. 7 IG. Similar cases concerning violations of the ECHR have been heard since $2005,{ }^{91}$ but these have generally been seen as recognition of the legal importance of Chap. 2 IG.

2.8.4 Regarding the review of measures implementing EU law, the jurisprudence is perhaps not entirely consistent or coherent. Normally, Swedish courts apply EU law loyally, including implemented directives, without advanced or sophisticated lines of reasoning concerning compatibility with the ECHR or the Swedish Constitution, but there are a few exceptions from the Supreme Courts. One such example is NJA 2001 (p. 409), concerning Directive 95/46 on the protection of individuals with regard to the processing of personal data and on the free movement of such data ${ }^{92}$ (transposed into Swedish law by the so-called Personuppgiftslagen, PuL, 1998:204). In this case, the Supreme Court clearly favoured and gave priority to the Freedom of the Press Act in a situation of conflict (referring also to Arts. 8 and 10 ECHR).

2.8.5 In the doctrine, some proposals have been made - not least in relation to treaty changes - to introduce a stricter review of the constitutionality of EU legislation, in line with that exercised by the German Constitutional Court. ${ }^{93}$ However, this debate has not been very vivid or influential. My own personal view is that there may be a need for such stricter review in some situations and that the Law Council may have a role to play, using its powers under Chap. 8, Arts. 20-22 IG (see above Sect. 2.1.3).

2.8.6 Equal treatment of those falling within the scope of EU and national law was one of the key aspects of the Lassagaird case of 1997 (RA 1997 ref. 65), mentioned above in Sect. 1.3.2. In that case the plaintiff applied to a regional administrative authority (Länsstyrelsen) for an agricultural subsidy in May 1995. The Lassagård case is of fundamental importance as to the extension of the scope of judicial review

\footnotetext{
owner was a professional translator who also worked with cartoons, but since 1998, any possession of such material has been illegal and the FPA does not apply in relation to such material (Chap. 1, Art. 10). Nevertheless, the Supreme Court used the rules on freedom of speech and freedom of information in the IG, including the rules determining when these freedoms may be limited (Chap. 2 Arts. 21 and 23) to decide that his possession of the material was justified, while stressing the difference between drawn art of this kind, depicting kids that are not recognisable and - with one exception - not even realistically portrayed and, on the other hand, photos or paintings based on living models. While the owner was sentenced to a fine by two lower courts, he was acquitted in the end by the Supreme Court.

90 T 5516-12, Judgment 23 April 2014.

${ }^{91}$ Starting with NJA 2005, p. 462. See also NJA 2012, p. 211 (I-II).

${ }^{92}$ Directive 95/46/EC of the European Parliament and of the Council of 24 October 1995 on the protection of individuals with regard to the processing of personal data and on the free movement of such data [1995] OJ L 281/31.

93 See e.g. Bergström 2008.
} 
in Sweden and its interaction with EU law. First, it follows clearly from the case that EU law prevails over domestic law. Secondly, it shows that EU law has extended the scope of judicial review in the Swedish legal order. The application of the general principle of effective protection by the Supreme Administrative Court resulted in the invalidation of the national regulation that limited review and the incorporation of a new provision ensuring the general competence of the administrative courts to review administrative decisions.

The importance of the case is shown not least when recalling that in a similar case, Stallknecht, which concerned the situation before 1995, both the Supreme Court and the Supreme Administrative Court refused to review an administrative decision against which no appeal existed (although the claim for economic compensation in question was in fact more justified than in Lassagård). ${ }^{94}$

\subsection{Other Constitutional Rights and Principles}

2.9.1 The implementation of EU law that affects individual rights by governmental regulations is not as such an issue in Sweden. However, the prohibition to introduce indictable offences by a governmental instrument also applies, as follows from Chap. 8, Art. 2, Sect. 1, p. 2 and Art. 3 Sect. 2. This is also illustrated by the 2005 Supreme Court case mentioned above in Sect. 2.1.3 under 'the rule of law'. 95

\subsection{Common Constitutional Traditions}

2.10.1 Generally speaking, it is difficult to elevate important constitutional traditions from one Member State by giving them the status of 'common constitutional traditions'. However, there is at least one example where the CJEU has allowed a national constitutional tradition to prevail over the free movement of services, namely the Omega Spielhallen case, where a local German prohibition against so-called laserdomes was upheld, since they were seen as violating human dignity. ${ }^{96}$

In Sweden, the content of common constitutional traditions has mainly been discussed in relation to specific Swedish rules on access to documents, transparency and protection of whistle-blowers, freedoms that are wider pursuant to the Freedom of the Press Act than under EU law. The issue of the relationship between these

\footnotetext{
${ }^{94}$ See NJA 1994, p. 657 and RÅ 1995, ref. 58, respectively.

${ }^{95}$ Case NJA 2005, p. 33; see the text accompanying supra n. 45.

${ }^{96}$ Case C-36/02 Omega [2004] ECR I-09609.
} 
Swedish constitutional freedoms and EU law is still unresolved. ${ }^{97}$ Subsequent developments within EU law, such as the stricter rules on access to documents and open administration ${ }^{98}$ and, not least, the recognition of the constitutional identity of the Member States now mentioned, since 2009, in Art. 4(2) TEU, may have reduced these tensions slightly. However, to show the underlying difficulties, in 2012, the Constitutional Committee of the Parliament, while exercising its so-called review of subsidiarity in accordance with Art. 69 TFEU, protested against the use of a regulation as the legal act for the introduction of new rules on the use of personal data, since the use of a directive for these same rules would have given the Member States greater legal space for action, including a necessary consideration of the national legal context. ${ }^{99}$ It may also be mentioned that in November 2013, the Swedish Parliament did, controversially and at least officially, without a specific request from the EU, approve new limitations of the general and widespread access to documents whenever their secrecy may be due to international co-operation or requested by an international organisation (including the EU). ${ }^{100}$ Many journalists and press organisations have reacted critically against these changes.

2.10.2 There is definitely a greater need to highlight national constitutional case law in preliminary references. One example of a Swedish case where this would definitely have been most useful is the Laval case mentioned above.

\subsection{Article 53 of the Charter and the Issue of Stricter Constitutional Standards}

2.11.1 As mentioned above, the Melloni case may simply be described as wrong in this respect, at least from the Swedish point of view, since it meant that the Spanish Constitutional Court was not allowed to invoke the Spanish Constitution (Art. 24) although it contained a higher level of human rights protection than guaranteed by the Charter of Fundamental Rights. This is contrary to the very wording of Art. 53 of the Charter and thus not acceptable. This issue has so far not been discussed much in Sweden. ${ }^{101}$ As noted above, we may hope that the CJEU will not maintain this low human rights standard, thus infringing human rights guaranteed in national constitutions. However, should this be the case, a very lively discussion is likely to start throughout Europe.

\footnotetext{
${ }^{97}$ See e.g. KU 1993/94:21, in particular p. 25 et seq., as well as Prop (Government Bill) 1993/ 94:114.

${ }^{98}$ See Art. 41 of the EU Charter of Fundamental Rights.

${ }^{99}$ See KU 2011/12:25.

${ }^{100}$ See KU 2013/14:6, Sekretess $i$ det internationella samarbetet (Privacy in international cooperation), as well as rskr 2013/14:59, leading to the law 2013:972 containing amendments to the Secrecy Law.

${ }^{101}$ See Nergelius 2013b.
} 


\subsection{Democratic Debate on Constitutional Rights and Values}

2.12.1 A certain amount of debate on the EAW Framework Decision took place in Parliament in 2003, and it may in particular be noted that the then Prime Minister, Fredrik Reinfeldt, who was then an MP and Chairman of the Law Committee of the Parliament, led the opposition in an attempt to stop or at least stall the Swedish implementation of the EAW. ${ }^{102}$ Resistance to the Data Retention Directive was even stronger, as described above in Sect. 2.4.

2.12.2 There may indeed be a need for more 'space', so to speak, for the Member States on these issues. At the same time, at the rather late implementation stage, Member States are expected to act loyally (cf. Art. 4(3) TEU), rather than to bring up issues of constitutionality or similar questions. The Swedish resistance against or reluctance towards the Data Retention Directive is thus a clear exception from what might be expected, and such behaviour must be reserved for situations where real human rights violations or otherwise unconstitutional legal acts are adopted by the EU.

2.12.3 The recommendation to suspend the application of an EU measure if important constitutional issues have been identified by a number of courts is an interesting idea and, if it could be enacted during the next treaty revision whenever that happens - it might actually be a useful tool for dealing with these kinds of situations in the future.

The defence of unconstitutionality in infringement proceedings merits support, not least because it may make the CJEU reconsider, in future cases, its rigid view on the relationship between EU law and national constitutions, as shown most recently in Melloni.

\subsection{Experts' Analysis on the Protection of Constitutional Rights in EU Law}

2.13.1 As noted above, with the exception of the Melloni judgment, the answer is no (i.e. there has been no general fall of standards).

2.13.2 Having answered no to the first question, I would only stress the risk of future different standards in the jurisprudences of the CJEU and the ECtHR. So far, the CJEU has applied the ECHR loyally, with a view to the interpretations of the ECtHR. However, the same rights in the Charter will never be applied by the ECtHR, which means that the CJEU might develop its own jurisprudence, setting its own standards, for some rights that are protected also in the ECHR. In the future,

${ }^{102}$ See JuU 2003/04:8. 
this could be a real problem. It is difficult to say whether the accession of the EU to the ECHR will prevent this (potential) problem.

2.13.3 With regard to the quotes in the Questionnaire, I think that the criticism towards the cryptic style of many judgments of the CJEU is highly justified. This concerns both the formalistic language and French-inspired style of writing as well as the lack of dissenting opinions. Generally speaking, judgments from the US Supreme Court, the House of Lords, the Bundesverfassungsgericht or even the ECtHR are simply much more interesting to read.

There are no clear examples of constitutional questions from Swedish courts to the CJEU, although issues related to access to documents, commercial advertising, the position of courts when asking for preliminary rulings related to the CILFIT criteria or the absence of abstract judicial review may be said to have constitutional implications. In all of these cases, ${ }^{103}$ the response from the CJEU has been adequate from the Swedish point of view. The judgment in the Lyckeskog case may be criticised for not being very informative concerning the scope of the CILFIT criteria, but that was remedied a year later by Köbler. ${ }^{104}$

Future 'actions' on the part of the CJEU which merit support include a stricter standard of judicial review of EU measures and allowing dissenting opinions; I support these two suggestions whole-heartedly. If it would be realistic to display the arguments in a case on the website, this sounds like a good idea, but some problems related to the integrity of CJEU procedure are foreseeable.

\section{Constitutional Issues in Global Governance}

\subsection{Constitutional Rules on International Organisations and the Ratification of Treaties}

3.1.1 Regarding specific international organisations, as mentioned in Sect. 1.2.1, since 2010, Chap. 1, Art. 10 IG mentions that Sweden participates in various forms of international cooperation, within the UN and the Council of Europe as well as 'in other contexts'. The Article provides as follows: 'Sweden is a member of the European Union. Sweden also participates in international cooperation within the framework of the United Nations and the Council of Europe, and in other contexts.'

The answer to the question on transfer of powers is more complicated. Here it may be said that Chap. 10, Art. 7 permits transfers of legislative powers, budgetary powers including the use of the assets of the state and treaty-making power, all to a

103 See Case C-101/01 Lindquist [2003] ECR I-12971; Case C-405/98 Gourmet [2001] ECR I-01795; Case C-99/00 Lyckeskog [2002] ECR I-04839 and Case C-432/05 Unibet [2007] ECR I-02271.

${ }^{104}$ Case C-224/01 Köbler [2003] ECR I-10239. 
limited extent, to international organisations other than the EU. The Article has the following wording:

Decision-making authority which is directly based on the present Instrument of Government and which relates to the laying down of provisions, the use of assets of the State, tasks connected with judicial or administrative functions, or the conclusion or denunciation of an international agreement or obligation may, in cases other than those under Art. 6, be transferred, to a limited extent, to an international organisation for peaceful cooperation of which Sweden is a member, or is about to become a member, or to an international court of law.

Decision-making authority relating to matters concerning the enactment, amendment or abrogation of fundamental law, the Riksdag Act or a law on elections for the Riksdag, or relating to the restriction of any of the rights and freedoms referred to in Chapter 2 may not be transferred under paragraph one.

A Riksdag decision in the matter of such transfer is taken in accordance with the procedure laid down in Art. 6, paragraph two.

Of importance here is also Chap. 10, Art. 8:

Any judicial or administrative function not directly based on this Instrument of Government may be transferred, in cases other than those under Article 6, to another state, international organisation, or foreign or international institution or community by means of a decision of the Riksdag. The Riksdag may authorise the Government or other public authority in law to approve such transfer of functions in particular cases.

Where the function concerned involves the exercise of public authority, the Riksdag's decision in the matter of such transfer or authorisation is taken in accordance with the procedure laid down in Article 6, paragraph two.

Furthermore, Chap. 10, Art. 9 states that

If it has been laid down in law that an international agreement shall have validity as Swedish law, the Riksdag may prescribe, by means of a decision taken in accordance with the procedure laid down in paragraph two, that also any future amendment of the agreement binding upon the Realm shall apply within the Realm. Such a decision shall relate only to a future amendment of limited extent.

Thus, the rules for concluding various types of treaties and agreements are now reasonably clear and updated.

3.1.2 Generally speaking, Chap. 10, Art. 6 was introduced when Sweden joined the European Union in 1995, while the other three articles mentioned date back to the enactment of the new Constitution in 1974 or even earlier. ${ }^{105}$ Already in 1964, the possibility to transfer decision-making powers to an international organisation aimed at peaceful co-operation was established, although this could only take place to a limited extent. Although these old provisions could not be used in order to facilitate EU membership, this constitutional reform was actually enacted as early as fifty years ago, with the future relation to the EC in mind (Sweden had applied

\footnotetext{
${ }^{105}$ A useful comment on the historical background of these articles and their history 'before 1995' was made by Algotsson 2000, p. 273 et seq.
} 
for association with the EC already in 1961). These rules were then transferred to the new Constitution in 1974, with the only addition that transfer of competences could also take place to an international court. ${ }^{106}$

3.1.3 The only case of importance in this regard is a judgment from 1996 concerning the current IG Chap. 10, Art. 8. It concerned the transfer of certain administrative functions on the border between Sweden and Finland to Finnish authorities and a transnational body, which had not been decided in a formally correct manner. ${ }^{107}$ A somewhat ironic twist in the case was that on 23 April 2014, some fishermen in the very north of Sweden were awarded financial compensation, after lengthy proceedings, since their right to property according to Chap. 2, Art. 15 IG had been violated by these errors. ${ }^{108}$

\subsection{The Position of International Law in National Law}

3.2.1 Treaties entered into by Sweden do not form part of the Swedish Constitution and are in fact not even part of Swedish law at all until they have been incorporated or transposed into Swedish national law. In other words, Sweden traditionally adheres to a dualistic view on the relationship between national and international law.

This may be illustrated by the fate of the ECHR. Sweden ratified the ECHR already in 1951 (although the jurisdiction of ECtHR was not acknowledged until 1966), but it was not incorporated into Swedish national law until 1995, when Sweden joined the EU. Thus, for forty-five years, the ECHR was not a part of Swedish law and, strictly speaking, could not be invoked in proceedings before Swedish courts. Still, it was used by the Supreme Courts as a means of interpretation, in particular in the late 1980s and early 1990s, when Sweden had been condemned by the ECtHR for violations in a number of cases (mainly concerning Art. 6). Thus, the ECHR was important in Swedish law before being incorporated, but this is a clear exception.

3.2.2 As mentioned above, Sweden together with the other Nordic countries still has a dualistic view on the relationship between national and international law. This is not likely to change as such, although this may of course be regarded as regrettable in today's globalised world.

\footnotetext{
${ }^{106}$ Some minor changes were also introduced in 1976 and 1985; see Algotsson 2000, p. 274.

107 NJA 1996, p. 370.

108 NJA 2014, p. 332.
} 


\subsection{Democratic Control}

3.3.1 Agreements with other states or multilateral international agreements are concluded by the Government, as mentioned above. This is logical given that the Government 'governs the Realm' according to Chap. 1, Art. 6 IG. Concerning parliamentary involvement, which has increased in recent years, see above Sect. 3.1.1.

Chapter 10, Art. 3, according to which, since 2003, the Government may not conclude any binding international agreement without the approval of Parliament, if the agreement presupposes the amendment or abrogation of an act of law or the enactment of a new act of law, or if it otherwise concerns a matter which is for the Riksdag to determine, was enacted after the approval of the Nice Treaty. It also applies to new EU treaties. Thus, new EU treaties must, according to IG Chap. 10 Art. 3 Sect. 2, and Chap. 10, Art. 6, be approved twice: first, the Parliament must approve the agreement as such, with a three-fourths majority or by two decisions with an election in the interim, and then a new, separate decision must be made, with the same formal requirements, concerning the transfer of power to the EU that the new or amended treaty will entail.

As stated above, the future TTIP agreement has recently been much discussed from this point of view.

3.3.2 Except for the EMU referendum in 2003, there have been no referendums in Sweden on treaties.

\subsection{Judicial Review}

3.4.1 This is basically an issue that concerns the ECHR, since other international conventions are very rarely (if ever) applied, given the dualist tradition. Further, as seen above, Swedish courts tend to use the ECHR ever more frequently, a development of which I personally approve.

\subsection{The Social Welfare Dimension of the Constitution}

3.5.1 Concerns about the impact of globalisation on the social state is much less the case than foreign observers of Sweden in general expect. Concerning social rights as such, mentioned in Chap. 1, Art. 2, public power shall be exercised with respect for the equal worth of all and the liberty and dignity of the private person. In Sect. 2 of the same Art., the Constitution commits the public authorities to the realisation of social, economic and cultural rights, as well as environmental and other rights, although these rights are in fact not legally protected as such by the Constitution or by the Swedish legal order, which may be slightly surprising for 
foreign scholars and commentators. Instead, Chap. 1, Art. 2 IG is a simple statement on the aims and purposes of governmental activities and public institutions in general, including the duty of public authorities to combat discrimination. ${ }^{109}$

\subsection{Constitutional Rights and Values in Selected Areas of Global Governance}

The most controversial rendition case concerned two Egyptians residing in Sweden, who were abducted to Egypt from a Swedish airport in December 2001. The operation was carried out by CIA agents who were assisted by Swedish police. The fact that the Swedish Government was aware of the action led to a rather big scandal when it was revealed two years later. The Government then chose to claim that the late Foreign Minister, Anna Lindh, had been responsible, but this has never really been proved or clarified.

Concerning inclusion in terrorist blacklists and the freezing of bank accounts, the case Al-Barakaat, which until late 2008 was closely connected with the Kadi case, is definitely important.

The Kadi and Al-Barakaat judgment of the CJEU from 2008 is well known. It may be noted that Al-Barakaat, an organisation helping Somali refugees in Sweden that had some economic ties with an alleged terrorist-linked bank in Somalia, preferred not to bring the case to a Swedish court to ask for a preliminary ruling from the CJEU, which may have been a procedural mistake since it slowed the proceedings.

In this case, the CJEU set aside the judgments of the EU General Court and found that the fundamental rights of the applicants - their right to be heard and to a legal remedy as well as the right to property - had been violated. ${ }^{110}$ A subsequent judgment from the CJEU in 2013 confirmed the ruling. ${ }^{111}$ This high standard of human rights protection must be welcomed, as opposed to the alarmingly low standard in the Melloni judgment of the same year, as discussed above.

Al-Barakaat, who enjoyed the informal support of the Swedish government during the proceedings, was finally removed from the UN sanctions list in autumn 2008.

\footnotetext{
${ }^{109}$ In the literature on social rights, see Lind 2009.

${ }^{110}$ Joined cases C-402/05 P and C-415/05 P Kadi and Al Barakaat International Foundation v. Council and Commission [2008] ECR I-06351.

${ }^{111}$ Kadi II, supra n. 85.
} 


\section{References}

Åhman K. (2011) Normprövning - Domstols kontroll av svensk lags förenlighet med Regeringsformen och Europarätten 2000-2010 (Norm review - Judicial review of the compatibility of Swedish law with the Constitution and EU law 2000-2010). Norstedts Law, Stockholm.

Algotsson K. (2000) Sveriges författning efter EU-anslutningen (Sweden's Constitution after EU accession). SNS förlag, Stockholm.

Andersson T. (1996) Effective Protection of Community Rights in Sweden - Judicial Review of Administrative Decisions applying the Common Agricultural Policy. In: Cameron I., Simoni A. (eds.) Dealing with Integration - Perspectives from Seminars on European Law 1995-96. Iustus, Uppsala, pp. 141-184.

Bergström C. (2008) Femton år senare: Lissabonfördraget och den svenska grundlagens reglering av EU (Fifteen years later: The Lisbon Treaty and the Swedish Constitution's Regulation of the EU). Europarättslig tidskrift (10th Anniversary Edition) 35:49 et seq.

Bernitz U. (2002a) European law in Sweden: its implementation and role in market and consumer law. Juridiska institutionen, Stockholm 2002.

Bernitz U. (2002b) Sverige och Europarätten (Sweden and EU law). Nordstedts Juridik AB, Stockholm. (original version of Bernitz 2002a).

Besselink L. (2007) The Dutch Constitution, the European Constitution and the Referendum in the Netherlands. In: Albi A., Ziller J. (eds.) The European Constitution and National Constitutions: Ratification and Beyond. Kluwer Law International, Alphen aan den Rhijn, pp. 113-123.

Herlin-Karnell E. (2007) The Swedish Supreme Court and the European Arrest Warrant. Europarättslig Tidskrift pp. 883-893.

Holmberg E., Stjernquist N. (eds.) (2003) Vår författning (Our Constitution), $13^{\text {th }}$ edn. Norstedts Juridik, Stockholm.

Karlson, N. (2009) Lagrådets roll - idag och imorgon (The role of the council - today and tomorrow). Svensk Juristtidning pp. 269-274.

Lind A.-S. (2009) Sociala rättigheter i förändring - En konstitutionellrättslig studie (Social rights in transition - a constitutional law study). Juridiska institutionen, Uppsala 2009.

Lindblom P.-H. (1997) Integrera mera? (Integrate more?) Svensk Juristtidning pp. 316 et seq.

Melin M., Schäder G. (1999) EU:s constitution (The Constitution of the EU), 4th edn. Norstedts Juridik, Stockholm.

Nergelius J. (1998a) Amsterdamfördraget och EU:s institutionella maktbalans (The Amsterdam Treaty and the EU's institutional balance of power). Norstedts Juridik, Stockholm.

Nergelius J. (1998b) The Impact of EC Law in Swedish National Law - A Cultural Revolution. In: Cameron I., Simoni A. (eds.) Dealing with Integration - Perspectives from Seminars on European Law 1995-96. Iustus, Uppsala, pp. 165-182.

Nergelius J. (2002) Reasons Why a Small Country Would Want to Become a Member of the European Union (Taking the Nordic Countries as Examples). Institut Suisse de Droit Comparé 45:265-276.

Nergelius J. (2008) En olaglig folkomröstning - Sverige och euron (An illegal referendum Sweden and the euro). Santérus, Stockholm.

Nergelius J. (2009) The Constitutional Dilemma of the European Union. Europa Law Publishing, Groningen.

Nergelius J. (2010) Svensk statsrätt (Swedish constitutional law), 2nd edn. Studentlitteratur, Lund.

Nergelius J. (2013a) Europakten - flexible integration som grund för euron och EU:s framtid (The Euro Pact - flexible integration due to the euro and the EU's future). In: Bakardjieva Engelbrekt A., Oxelheim L., Persson T. (eds.) Ett konkurrenskraftigt EU till rätt pris (A competitive EU at the right price). Santérus Förlag, Stockholm 2013, pp. 61-83.

Nergelius J. (2013b) Comment on Melloni. Europarättslig tidskrift, pp. 815-819.

Nergelius J. (2014) Svensk statsrätt (Swedish constitutional law), 3rd edn. Studentlitteratur, Lund. 
Raz J. (1998) On the Authority and Interpretation of Constitutions: Some Preliminaries. In: Alexander L. (ed.) Constitutionalism - Philosophical Foundations. Cambridge University Press, Cambridge, pp. 152-193.

Zetterquist O. (2012) Strasbourg, Luxembourg - we have a problem - Reflektioner om ett litet HD-uppror (Reflections on a minor Supreme Court Rebellion). In: Derlén M., Lindholm J. (eds.) Festskrift till Pär Hallström (Festschrift in Honour of Pär Hallström). Iustus förlag, Uppsala, pp. 353 et seq.

Open Access This chapter is licensed under the terms of the Creative Commons Attribution 4.0 International License (http://creativecommons.org/licenses/by/4.0/), which permits use, sharing, adaptation, distribution and reproduction in any medium or format, as long as you give appropriate credit to the original author(s) and the source, provide a link to the Creative Commons license and indicate if changes were made.

The images or other third party material in this chapter are included in the chapter's Creative Commons license, unless indicated otherwise in a credit line to the material. If material is not included in the chapter's Creative Commons license and your intended use is not permitted by statutory regulation or exceeds the permitted use, you will need to obtain permission directly from the copyright holder.

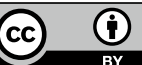

